NCCN

\section{Kidney Cancer,} Version 2.2017

\section{Clinical Practice Guidelines in Oncology}

Robert J. Motzer, MD; Eric Jonasch, MD; Neeraj Agarwal, MD; Sam Bhayani, MD; William P. Bro, BS; Sam S. Chang, MD;

Toni K. Choueiri, MD; Brian A. Costello, MD, MS; Ithaar H. Derweesh, MD; Mayer Fishman, MD, PhD; Thomas H. Gallagher, MD; John L. Gore, MD, MS; Steven L. Hancock, MD; Michael R. Harrison, MD; Won Kim, MD; Christos Kyriakopoulos, MD; Chad LaGrange, MD;

Elaine T. Lam, MD; Clayton Lau, MD;

M. Dror Michaelson, MD, PhD; Thomas Olencki, DO;

Phillip M. Pierorazio, MD; Elizabeth R. Plimack, MD, MS;
Bruce G. Redman, DO; Brian Shuch, MD; Brad Somer, MD; Guru Sonpavde, MD; Jeffrey Sosman, MD; Mary Dwyer, MS; and Rashmi Kumar, PhD

\section{Overview}

An estimated 62,700 Americans were diagnosed with renal cancer and 14,240 died of the disease in 2016. ${ }^{1}$ Renal cell carcinoma (RCC) constitutes approximately $3.8 \%$ of all new cancers, with a median age at diagnosis of 64 years. Approximately $90 \%$ of renal tumors are RCC, and approximately $80 \%$ of these are clear cell tumors. ${ }^{2,3}$ Other less common cell types include papillary, chromophobe, translocation, and Bellini duct (collecting duct) tumors. Medullary renal carcinoma is a variant of collecting duct renal

\begin{abstract}
The NCCN Guidelines for Kidney Cancer provide multidisciplinary recommendations for the clinical management of patients with clear cell and non-clear cell renal carcinoma. These guidelines are developed by a multidisciplinary panel of leading experts from NCCN Member Institutions consisting of medical oncologists, hematologists and hematologic oncologists, radiation oncologists, urologists, and pathologists. The NCCN Guidelines are in continuous evolution and are updated annually or sometimes more often, if new high-quality clinical data become available in the interim.
\end{abstract}

J Natl Compr Canc Netw 2017;15(6):804-834 doi:10.6004/jnccn.2017.0100

NCCN Categories of Evidence and Consensus Category 1: Based upon high-level evidence, there is uniform NCCN consensus that the intervention is appropriate.

Category 2A: Based upon lower-level evidence, there is uniform NCCN consensus that the intervention is appropriate.

Category 2B: Based upon lower-level evidence, there is NCCN consensus that the intervention is appropriate. Category 3: Based upon any level of evidence, there is major NCCN disagreement that the intervention is appropriate.

All recommendations are category 2A unless otherwise noted.

Clinical trials: NCCN believes that the best management for any cancer patient is in a clinical trial. Participation in clinical trials is especially encouraged.

\section{Please Note}

The NCCN Clinical Practice Guidelines in Oncology $\left(\mathrm{NCCN}\right.$ Guidelines ${ }^{\circledR}$ ) are a statement of consensus of the authors regarding their views of currently accepted approaches to treatment. Any clinician seeking to apply or consult the NCCN Guidelines ${ }^{\circledR}$ is expected to use independent medical judgment in the context of individual clinical circumstances to determine any patient's care or treatment. The National Comprehensive Cancer Network $^{\circledR}\left(\mathrm{NCCN}^{\circledR}\right)$ makes no representation or warranties of any kind regarding their content, use, or application and disclaims any responsibility for their applications or use in any way. The full NCCN Guidelines for Kidney Cancer are not printed in this issue of JNCCN but can be accessed online at NCCN.org.

(C) National Comprehensive Cancer Network, Inc. 2017, All rights reserved. The NCCN Guidelines and the illustrations herein may not be reproduced in any form without the express written permission of NCCN.

\section{Disclosures for the NCCN Kidney Cancer Panel}

At the beginning of each NCCN Guidelines panel meeting, panel members review all potential conflicts of interest. NCCN, in keeping with its commitment to public transparency, publishes these disclosures for panel members, staff, and NCCN itself.

Individual disclosures for the NCCN Kidney Cancer Panel members can be found on page 834. (The most recent version of these guidelines and accompanying disclosures are available on the NCCN Web site at NCCN.org.)

These guidelines are also available on the Internet. For the latest update, visit NCCN.org. 


\section{Journal of the National Comprehensive Cancer Network}

carcinoma and was described initially as occurring in patients who are sickle cell trait-positive.

Smoking and obesity are established risk factors for RCC development. Several hereditary types of RCC also exist, with von Hippel-Lindau (VHL) disease being the most common. VHL disease is caused by an autosomal-dominant constitutional mutation in the VHL gene that predisposes to clear cell RCC and other proliferative vascular lesions. ${ }^{4,5}$ Analysis of the SEER database indicates that renal cell cancer incidence has been increasing on average $1.1 \%$ each year and death rates have been declining on average $0.7 \%$ each year from 2004 through 2013.6 The 5-year survival rate for localized cancer has increased from $88.4 \%$ (during 1992-1995) to $92.5 \%$ (during 2006-2012) and for advanced disease from $7.3 \%$ (during 1992-1995) to $11.6 \%$ (during 2006-2012). ${ }^{6}$ The most important prognostic

determinants of 5-year survival are the tumor stage, grade, local extent of the tumor, presence of regional nodal metastases, and evidence of metastatic disease at presentation. ${ }^{7-16}$ RCC primarily metastasizes to the lung, lymph nodes, bone, liver, adrenal gland, and brain. ${ }^{5}$

\section{Initial Evaluation and Staging}

Patients with RCC typically present with a suspicious mass involving the kidney that was visualized through a radiographic study, often a CT scan. As the use of imaging methods (eg, abdominal CT with or without pelvic CT, ultrasound) has become more widespread, the frequency of incidental detection of RCC has increased ${ }^{17,18}$ and

Text cont. on page 813 .

\section{NCCN Kidney Cancer Panel Members}

*Robert J. Motzer, MD/ChairtP

Memorial Sloan Kettering Cancer Center

*Eric Jonasch, MD/Vice-Chairt

The University of Texas MD Anderson Cancer Center

Neeraj Agarwal, MD‡†

Huntsman Cancer Institute at the University of Utah

Sam Bhayani, MDW

Siteman Cancer Center at Barnes-Jewish Hospital and

Washington University School of Medicine

William P. Bro, BS¥

Kidney Cancer Association

Sam S. Chang, MDW

Vanderbilt-Ingram Cancer Center

Toni K. Choueiri, MD+P

Dana-Farber/Brigham and Women's Cancer Center

Brian A. Costello, MD, MSt

Mayo Clinic Cancer Center

Ithaar H. Derweesh, MDW

UC San Diego Moores Cancer Center

Mayer Fishman, MD, PhDtP $\ddagger$

Moffitt Cancer Center

Thomas H. Gallagher, MDP

Fred Hutchinson Cancer Research Center/

Seattle Cancer Care Alliance

John L. Gore, MD, MSW

Fred Hutchinson Cancer Research Center/

Seattle Cancer Care Alliance

Steven L. Hancock, MD§P

Stanford Cancer Institute

Michael R. Harrison, MD†

Duke Cancer Institute

Won Kim, MD†

UCSF Helen Diller Family Comprehensive Cancer Center

Christos Kyriakopoulos, MD

University of Wisconsin Carbone Cancer Center

Chad LaGrange, MD $\omega$

Fred \& Pamela Buffett Cancer Center
Elaine T. Lam, MD†

University of Colorado Cancer Center

Clayton Lau, MDW

City of Hope Comprehensive Cancer Center

M. Dror Michaelson, MD, PhD†

Massachusetts General Hospital Cancer Center

Thomas Olencki, DOt

The Ohio State University Comprehensive Cancer Center James Cancer Hospital and Solove Research Institute

Phillip M. Pierorazio, MD $\omega$

The Sidney Kimmel Comprehensive Cancer Center at Johns Hopkins

Elizabeth R. Plimack, MD, MS†

Fox Chase Cancer Center

Bruce G. Redman, DO† University of Michigan Comprehensive Cancer Center

Brian Shuch, MD $\omega$

Yale Cancer Center/Smilow Cancer Hospital

Brad Somer, MD†

St. Jude Children's Research Hospital/ University of Tennessee Cancer Institute

Guru Sonpavde, MDt

University of Alabama at Birmingham

Comprehensive Cancer Center

Jeffrey Sosman, MD¥

Robert H. Lurie Comprehensive Cancer Center of Northwestern University

NCCN Staff: Mary Dwyer, MS, and Rashmi Kumar, PhD

KEY:

*Discussion Section Writing Committee

Specialties: †Medical Oncology; ¥Hematology/Hematology Oncology; §Radiotherapy/Radiation Oncology; PInternal

Medicine; $\omega$ Urology; $\neq$ Pathology; ¥Patient Advocacy 


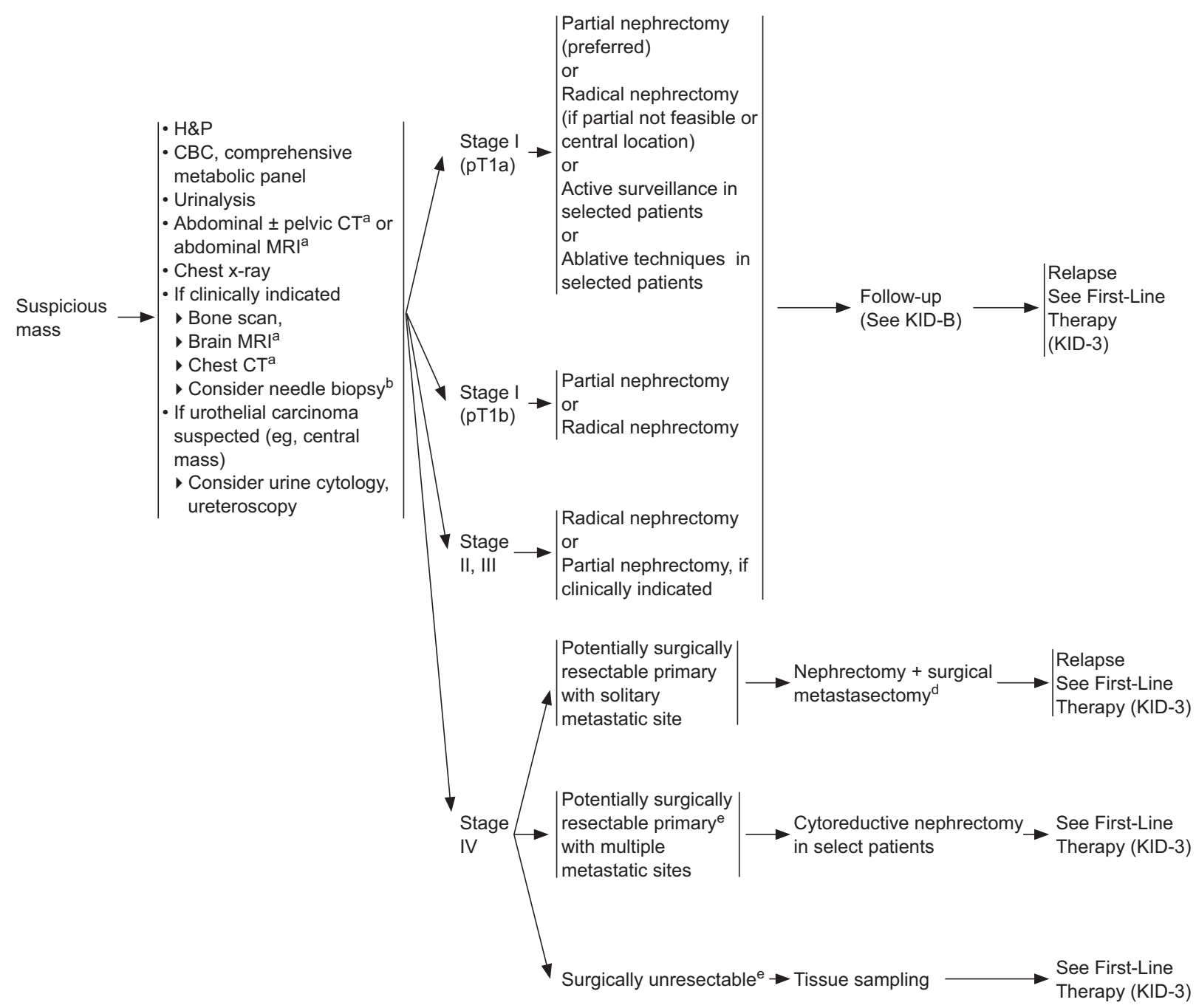

\footnotetext{
almaging with contrast when clinically indicated.

bBiopsy of small lesions may be considered to obtain or confirm a diagnosis of malignancy and guide surveillance, cryosurgery, and radiofrequency ablation strategies.

cSee Principles of Surgery (KID-A).

dNo single follow-up plan is appropriate for all patients. Follow-up should be individualized based on patient requirements.

eIndividualize treatment based on symptoms and extent of metastatic disease.
}

KID-1

KID-2 


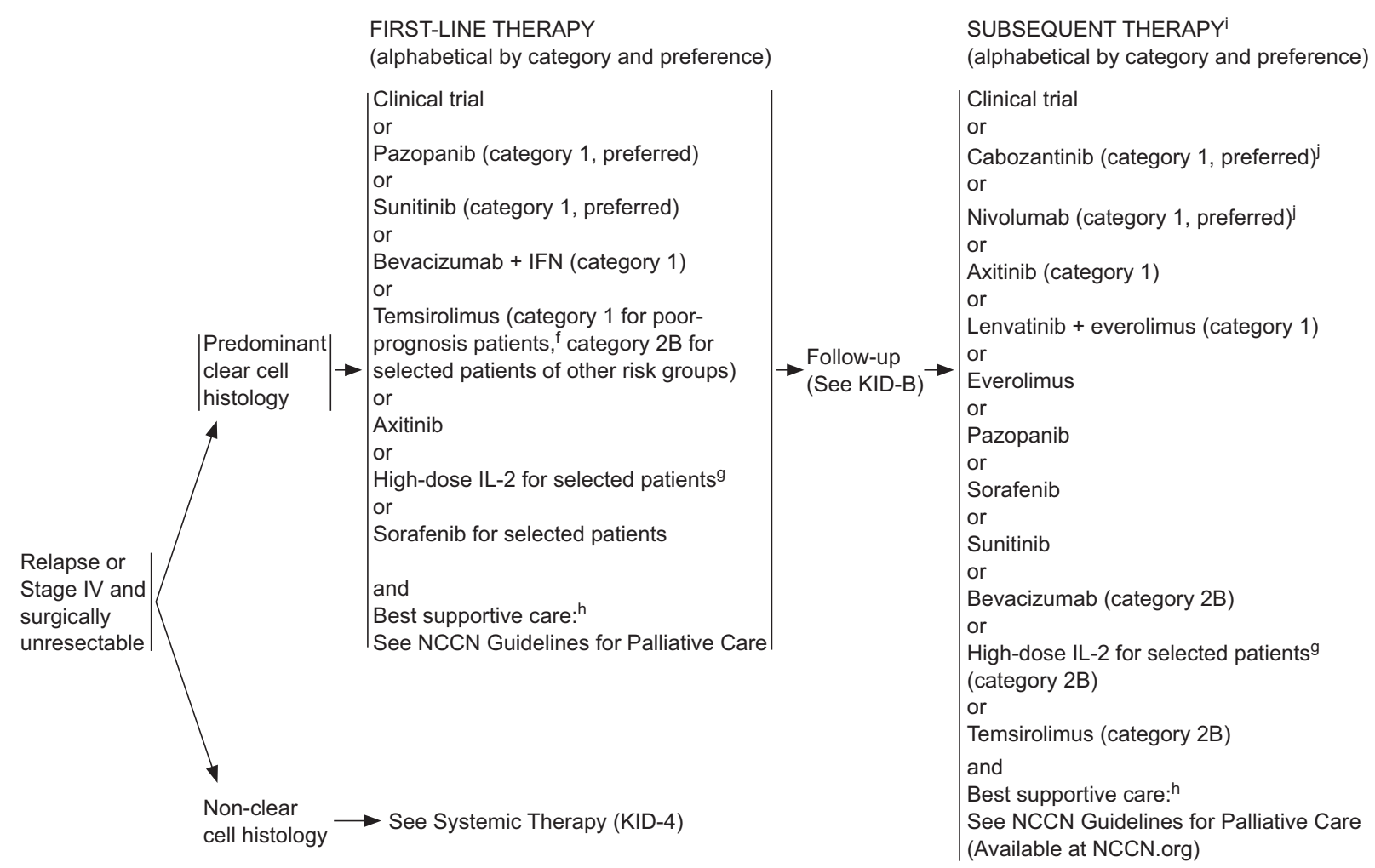

fPoor-prognosis patients, defined as those with $\geq 3$ predictors of short survival.

See Predictors of Short Survival Used to Select Patients for Temsirolimus (KID-C).

gPatients with excellent performance status and normal organ function.

hBest supportive care can include palliative RT, metastasectomy, bisphosphonates, or RANK ligand inhibitors for bony metastases.

iIn clear cell and non-clear cell RCC with predominant sarcomatoid features, gemcitabine + doxorubicin (category $2 \mathrm{~B}$ ) and gemcitabine + sunitinib

(category 2B) have shown benefit.

jBased on the results of phase III trials, eligible patients should preferentially receive this agent over everolimus. See Discussion.

KID-3

Version 2.2017, 10-31-16 @2017 National Comprehensive Cancer Network, Inc. All rights reserved. The NCCN Guidelines ${ }^{\circledR}$ and this illustration may not be reproduced in any form without the express written permission of $\mathrm{NCCN}^{\circledR}$. 


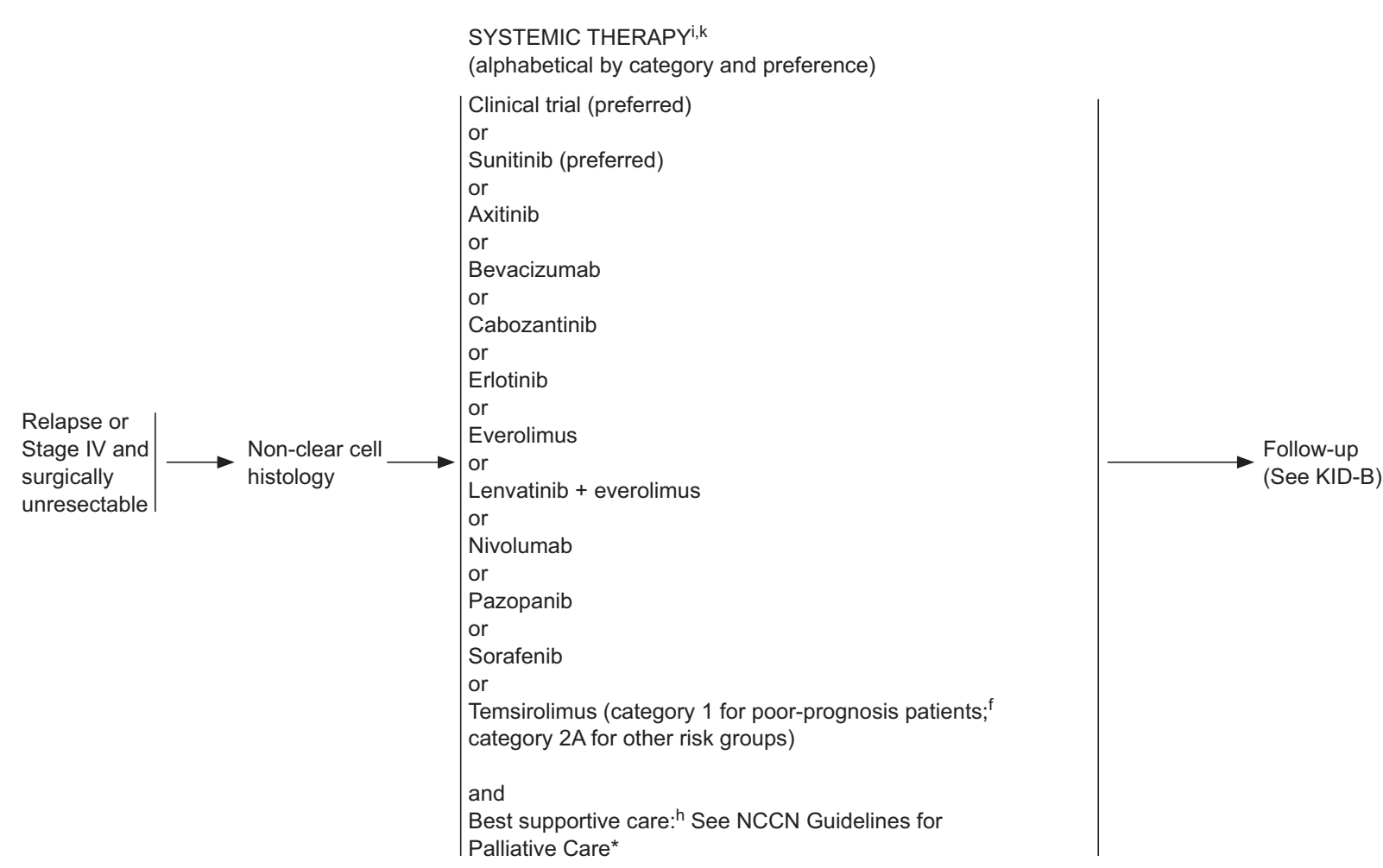

${ }^{*}$ Available at NCCN.org

fPoor-prognosis patients, defined as those with $\geq 3$ predictors of short survival. See Predictors of Short Survival Used to Select Patients for Temsirolimus (KID-C).

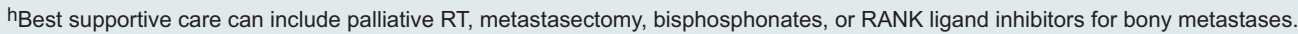

iln clear cell and non-clear cell RCC with predominant sarcomatoid features, gemcitabine + doxorubicin (category 2B) and gemcitabine + sunitinib (category 2B) have shown benefit.

kPartial responses have been observed for cytotoxic chemotherapy (carboplatin + gemcitabine, carboplatin + paclitaxel, or cisplatin + gemcitabine) with collecting duct or medullary subtypes.

KID-4

Clinical trials: NCCN believes that the best management of any cancer patient is in a clinical trial. Participation in clinical trials is especially encouraged. All recommendations are category $2 \mathrm{~A}$ unless otherwise indicated.

(C) JNCCN_Journal of the National Comprehensive Cancer Network | Volume 15 Number 6 | June 2017 
PRINCIPLES OF SURGERY

- Nephron-sparing surgery (partial nephrectomy) is appropriate in selected patients, for example:

- Unilateral Stage I-III tumors where technically feasible

- Uninephric state, renal insufficiency, bilateral renal masses, and familial renal cell cancer

- Open, laparoscopic, or robotic surgical techniques may be used to perform radical and partial nephrectomies.

- Regional lymph node dissection is optional but is recommended for patients with adenopathy on preoperative imaging or palpable/visible adenopathy at time of surgery.

- If adrenal gland is uninvolved, resection may be omitted.

- Special teams may be required for extensive inferior vena cava involvement.

- Observation or ablative techniques (eg, cryosurgery, radiofrequency ablation):

- Can be considered for selected patients with clinical stage T1 renal lesions.

- Biopsy of small lesions may be considered to obtain or confirm a diagnosis of malignancy and guide surveillance, cryosurgery, and radiofrequency ablation strategies.

- Randomized phase III comparison with surgical resection (ie, radical or partial nephrectomy by open or laparoscopic techniques) has not been done.

- Ablative techniques are associated with a higher local recurrence rate than conventional surgery.,

- Generally, patients who would be candidates for cytoreductive nephrectomy prior to systemic therapy have:

- Excellent performance status (ECOG PS <2)

- No brain metastasis

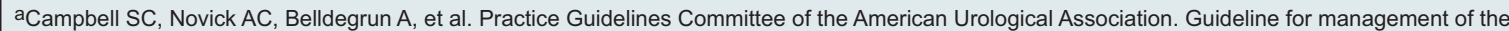
clinical T1 renal mass. J Urol 2009;182:1271-1279.

${ }^{b}$ Kunkle DA, Uzzo RG. Cryoablation or radiofrequency ablation of the small renal mass: A meta-analysis. Cancer 2008;113:2671-2680.

KID-A 
Stage I (pT1a)

Follow-up During Active Surveillance ${ }^{c}$

- H\&P every 6 mo for $2 y$, then annually up to $5 y$ after diagnosis

- Comprehensive metabolic panel and other tests as indicated every 6 mo for first $2 \mathrm{y}$, then annually up to 5 y after diagnosis

- Abdominal imaging:

- Abdominal CT or MRI within 6 mo of surveillance initiation, then CT, MRI, or US at least annually

- Chest imaging:

- Chest x-ray or CT annually to assess for pulmonary metastases, if biopsy positive for RCC

- Pelvic CT or MRI, as clinically indicated

- CT or MRI of head or MRI of spine, as clinically indicated

- Bone scan, as clinically indicated

Follow-up After Ablative Techniques ${ }^{c}$

- H\&P every 6 mo for $2 \mathrm{y}$, then annually up to $5 \mathrm{y}$ after diagnosis

- Comprehensive metabolic panel and other tests as indicated every 6 mo for first $2 \mathrm{y}$, then annually up to $5 \mathrm{y}$ after diagnosis

- Abdominal imaging:

- Abdominal CT or MRI at 3-6 mo following ablative therapy unless otherwise contraindicated then CT, MRI, or US annually for $5 \mathrm{y}$ - Chest imaging:

- Chest x-ray or CT annually for 5 y for patients who have biopsy-proven low-risk RCC, nondiagnostic biopsies, or no prior biopsy - Repeat biopsy:

- New enhancement, a progressive increase in size of an ablated neoplasm, new nodularity in or around the treated zone, failure of the treated lesion to regress over time, satellite or port site lesions

- Pelvic CT or MRI, as clinically indicated

- CT or MRI of head or MRI of spine, as clinically indicated

- Bone scan, as clinically indicated

\section{Stage I (pT1a) and (pT1b)}

\section{Follow-up After a Partial or Radical Nephrectomy}

- H\&P every 6 mo for $2 y$, then annually up to 5 y after nephrectomy

- Comprehensive metabolic panel and other tests as indicated every 6 mo for $2 \mathrm{y}$, then annually up to $5 \mathrm{y}$ after nephrectomy

- Abdominal imaging:

- After partial nephrectomy:

$\checkmark$ Baseline abdominal CT, MRI, or US within 3-12 mo of surgery

$\checkmark$ If the initial postoperative scan is negative, abdominal CT, MRI, or US may be considered annually for 3 y based on individual risk factors

- After radical nephrectomy:

$\checkmark$ Patients should undergo abdominal CT, MRI, or US within 3-12 mo of surgery

$\checkmark$ If the initial postoperative imaging is negative, abdominal imaging beyond 12 mo may be performed at the discretion of the physician - Chest imaging: Chest x-ray or CT annually for $3 \mathrm{y}$, then as clinically indicated

- Pelvic CT or MRI, as clinically indicated

- CT or MRI of head or MRI of spine, as clinically indicated

- Bone scan, as clinically indicated

aDonat SM, Diaz M, Bishoff JT, et al. Follow-up for clinically localized renal neoplasms: AUA Guideline. J Urol 2013;190:407-416.

bNo single follow-up plan is appropriate for all patients. Follow-up frequency and duration should be individualized based on patient requirements, and may be extended beyond 5 years at the discretion of the physician. Further study is required to define optimal follow-up duration.

CImaging with contrast when clinically indicated.

KID-B 1 OF 4

KID-B 2 OF 4

Clinical trials: NCCN believes that the best management of any cancer patient is in a clinical trial. Participation in clinical trials is especially encouraged. All recommendations are category $2 \mathrm{~A}$ unless otherwise indicated. 
Stage II or III

Follow-up After a Radical Nephrectomy ${ }^{\mathrm{C}}$

- H\&P every 3-6 mo for $3 y$, then annually up to $5 y$ after radical nephrectomy and then as clinically indicated thereafter

- Comprehensive metabolic panel and other tests as indicated every 6 mo for $2 \mathrm{y}$, then annually up to $5 \mathrm{y}$ after radical nephrectomy, then

as clinically indicated thereafter

- Abdominal imaging:

- Baseline abdominal CT or MRI within 3-6 mo, then CT, MRI, or US (US is category 2B for Stage III),

every 3-6 mo for at least 3 y and then annually up to 5 y

- Imaging beyond $5 \mathrm{y}$ : as clinically indicated

- Site-specific imaging: as symptoms warrant

- Chest imaging:

- Baseline chest CT within 3-6 mo after radical nephrectomy with continued imaging (CT or chest $x$-ray) every 3-6 mo for at least 3 y and then annually up to $5 \mathrm{y}$

- Imaging beyond $5 \mathrm{y}$ : as clinically indicated based on individual patient characteristics and tumor risk factors

- Pelvic CT or MRI, as clinically indicated

- CT or MRI of head or MRI of spine, as clinically indicated

- Bone scan, as clinically indicated

Follow-up for Relapsed or Stage IV and Surgically Unresectable Disease ${ }^{c, d}$

$\cdot$ H\&P every 6-16 weeks for patients receiving systemic therapy, or more frequently as clinically indicated and adjusted for type of systemic therapy patient is receiving

- Laboratory evaluation as per requirements for therapeutic agent being used

- Chest, abdominal, and pelvic imaging:

- CT or MRI imaging to assess baseline pretreatment or prior to observation

- Follow-up imaging every 6-16 weeks as per physician discretion and per patient clinical status. Imaging interval to be adjusted upward and downward according to rate of disease change and sites of active disease

- Consider CT or MRI of head at baseline and as clinically indicated. Annual surveillance scans at physician discretion

- MRI of spine as clinically indicated

- Bone scan as clinically indicated

aDonat SM, Diaz M, Bishoff JT, et al. Follow-up for clinically localized renal neoplasms: AUA Guideline. J Urol 2013;190:407-416.

bNo single follow-up plan is appropriate for all patients. Follow-up frequency and duration should be individualized based on patient requirements, and may be extended beyond 5 years at the discretion of the physician. Further study is required to define optimal follow-up duration.

CImaging with contrast when clinically indicated.

d No single follow-up plan is appropriate for all patients. Follow-up should be individualized based on treatment schedules, side effects, comorbidities, and symptoms. 
Poor-prognosis patients are defined as those with $\geq 3$ predictors of short survival.

- Lactate dehydrogenase level $>1.5$ times upper limit of normal

- Hemoglobin level < lower limit of normal

- Corrected serum calcium level $>10 \mathrm{mg} / \mathrm{dL}$ ( $2.5 \mathrm{mmol} /$ liter $)$

- Interval of less than a year from original diagnosis to the start of systemic therapy

- Karnofsky performance score $\leq 70$

$\cdot \geq 2$ sites of organ metastasis 
fewer patients present with the typical triad symptoms (hematuria, flank mass, and flank pain).

Less frequently, patients present with signs or symptoms resulting from metastatic disease, including bone pain, adenopathy, and pulmonary symptoms attributable to lung parenchyma or mediastinal metastases. Other presentations include fever, weight loss, anemia, or a varicocele. RCC in younger patients ( $\leq 46$ years) may indicate an inheritable disorder, ${ }^{19}$ and these patients should be referred to a hereditary cancer clinic for further evaluation.

A thorough physical examination should be performed and a complete medical history should be obtained. Laboratory evaluation includes a CBC count and comprehensive metabolic panel. The metabolic panel may include serum-corrected calcium, serum creatinine, liver function studies, and urinalysis.

CT of the abdomen with or without pelvic CT and chest radiograph are essential studies in the initial workup. ${ }^{20}$ For metastatic evaluation, at the very least, chest radiography must be performed, although chest CT is more accurate than chest radiograph for chest staging. ${ }^{21-23}$

Abdominal MRI is used to evaluate the inferior vena cava if tumor involvement is suspected, or it can be used instead of CT for detecting renal masses and for staging when contrast material cannot be administered because of allergy or moderate renal insufficiency. ${ }^{24,25}$ All imaging studies may be performed with contrast, if indicated.

A central renal mass may suggest the presence of urothelial carcinoma; if so, urine cytology, uteroscopy, and biopsy should be considered.

Most bone and brain metastases are symptomatic at diagnosis. Therefore, a bone scan is not routinely performed unless the patient has an elevated serum alkaline phosphatase (ALP) or complains of bone pain. ${ }^{26} \mathrm{CT}$ or MRI of the brain can be performed if clinical signs, presentation, and symptoms suggest brain metastases.

The recommended abdominal imaging studies provide high diagnostic accuracy. Therefore, a needle biopsy is not always necessary before surgery, especially in patients with clear findings in the imaging studies. In selected individuals, needle biopsy may be considered for small lesions to establish diagnosis of RCC and guide active surveillance strategies, cryosurgery, radiofrequency, and ablation strategies. ${ }^{27}$ As noted earlier, biopsy should also be considered if a central lesion or a homogeneous infiltration of renal parenchyma is observed on scans to rule out urothelial carcinoma or lymphoma, respectively.

The value of PET in RCC remains to be determined. Currently, PET alone is not a tool that is standardly used to diagnose kidney cancer or follow for evidence of relapse after nephrectomy. ${ }^{28}$

The use of current TNM classification ${ }^{29}$ and classification of histologic subtypes ${ }^{30}$ are important in making treatment decisions.

\section{Treatment of Localized Disease}

Surgical resection remains an effective therapy for clinically localized RCC, with options including radical nephrectomy and nephron-sparing surgery. Each of these modalities is associated with its own benefits and risks, the balance of which should optimize longterm renal function and expected cancer-free survival.

\section{Nephron-Sparing Surgery and Radical Nephrectomy}

A radical nephrectomy includes a perifascial resection of the kidney, perirenal fat, regional lymph nodes, and ipsilateral adrenal gland. Radical nephrectomy is the preferred treatment if the tumor extends into the inferior vena cava. Open, laparoscopic, or robotic surgical techniques may be used to perform radical nephrectomy. Long-term outcomes data indicate that laparoscopic and open radical nephrectomies have equivalent cancer-free survival rates. ${ }^{31-38}$

Originally, partial nephrectomy (nephron-sparing surgery) was indicated only in clinical settings in which a radical nephrectomy would render the patient functionally anephric, necessitating dialysis. These settings include RCC in a solitary kidney, RCC in one kidney with inadequate contralateral renal function, and bilateral synchronous RCC.

Partial nephrectomy has well-established oncologic outcomes data comparable to radical nephrectomy. ${ }^{39-44}$ Radical nephrectomy can lead to an increased risk for chronic kidney disease ${ }^{45,46}$ and is associated with increased risks of cardiovascular morbidity and mortality according to population-based studies. ${ }^{47}$ When compared with radical nephrectomy, partial nephrectomy can achieve preserved renal function, decreased overall mortality, and reduced frequency of cardiovascular events. ${ }^{47-51}$ Patients 
with a hereditary form of RCC, such as VHL disease, should also be considered for nephron-sparing therapy. Nephron-sparing surgery has been used increasingly in patients with $\mathrm{T} 1 \mathrm{a}$ and $\mathrm{T} 1 \mathrm{~b}$ renal tumors (ie, up to $7 \mathrm{~cm}$ in greatest dimension) and a normal contralateral kidney, with equivalent outcomes to radical nephrectomy. ${ }^{42,52-54}$ Radical nephrectomy should not be used when nephron sparing can be achieved. A more recent study showed that among Medicare beneficiaries with early-stage kidney cancer, treatment with partial rather than radical nephrectomy was associated with improved survival..$^{55}$

Studies with limited follow-up data show that the oncologic outcome for laparoscopic versus open nephron-sparing surgery appears to be similar..$^{56,57}$ A study of oncologic outcomes at 7 years after surgery found metastasis-free survival to be $97.5 \%$ and 97.3\% $(P=.47)$ after laparoscopic and open nephronsparing surgery, respectively. ${ }^{58}$

The goals of nephron-sparing surgery should be optimal locoregional tumor control while minimizing ischemia time to ideally $<30$ minutes. ${ }^{59}$ However, in some patients with localized RCC, nephron-sparing surgery may not be suitable because of locally advanced tumor growth or because tumor is in an unfavorable location. Laparoscopic, robotic, and open partial nephrectomy all offer comparable outcomes in the hands of skilled surgeons. Patients in satisfactory medical condition should undergo surgical excision of stage I-III tumors.

\section{Lymph Node Dissection}

Lymph node dissection has not been consistently shown to provide therapeutic benefit. The EORTC phase III trial comparing radical nephrectomy with a complete lymph node dissection versus radical nephrectomy alone showed no significant differences in overall survival (OS), time to disease progression, or progression-free survival (PFS) between the study groups. ${ }^{60}$ However, primary tumor pathologic features, such as nuclear grade, sarcomatoid component, tumor size, stage, and presence of tumor necrosis, were all factors that influenced the likelihood of regional lymph node involvement at the time of radical nephrectomy ${ }^{61}$ Assessment of lymph nodes status is based on enlargement of imaging (CT/MRI) and on evaluation through direct palpation at time of surgery. CT/MRI may not detect small metastases in normal lymph nodes. ${ }^{62}$
The NCCN Kidney Cancer Panel recommends regional lymph nodedissection for patients with palpable or enlarged lymph nodes detected on preoperative imaging tests.

\section{Adrenalectomy}

Ipsilateral adrenal gland resection should be considered for patients with large upper pole tumors or abnormal-appearing adrenal glands on CT. ${ }^{63-65} \mathrm{Ad}$ renalectomy is not indicated when imaging shows a normal adrenal gland or if the tumor is not high-risk, based on size and location. ${ }^{66}$

\section{Active Surveillance and Ablative Techniques}

Active surveillance ${ }^{67,68}$ is defined as the initial monitoring of tumors using abdominal imaging techniques with delayed intervention when indicated. Elderly patients and those with small renal masses and other comorbidities often have a low RCC-specific mortality. ${ }^{69}$ Active surveillance and ablative techniques such as cryoablation or radiofrequency ablation are alternative strategies for selected patients, particularly the elderly and those with competing health risks.

Randomized phase III comparison of ablative techniques with surgical resection (ie, radical or partial nephrectomy by open or laparoscopic techniques) has not been performed.

The NCCN panel has addressed the utility of each of these treatment modalities for localized disease in the context of tumor stages I (pT1a and pT1b), II, and III.

\section{Management of Stage I (pT1a) Disease}

The NCCN panel prefers surgical excision by partial nephrectomy for the management of clinical stage I (pT1a) renal masses. Adequate expertise and careful patient selection are important. Partial nephrectomy is most appropriate in patients with small unilateral tumors or whenever preservation of renal function is a primary issue, such as in patients having one kidney or those with renal insufficiency, bilateral renal masses, or familial RCC. Both open and laparoscopic approaches to partial nephrectomy can be considered, depending on tumor size, location, and surgeon expertise.

Some localized renal tumors may not be amenable to partial nephrectomy, in which case radical 
nephrectomy is recommended. The NCCN Guidelines also list radical nephrectomy as an alternative for patients with stage I (pT1a) RCC if a partial nephrectomy is not technically feasible, as determined by the urologic surgeon.

Other options in selected patients with stage I (T1a) RCC include active surveillance and ablative techniques. Active surveillance is an option for the management of localized renal masses and should be a primary consideration for patients with decreased life expectancy or extensive comorbidities that would place them at excessive risk for more invasive intervention. Short- and intermediate-term oncologic outcomes indicate that an appropriate strategy is to initially monitor small renal masses, and, if required, treat for progression. ${ }^{67}$

Although distant recurrence-free survival rates of ablative techniques and conventional surgery are comparable, ablative techniques have been associated with an increased risk of local recurrence. ${ }^{70-73}$ Judicious patient selection and counseling remain of paramount importance for these less invasive technologies.

The NCCN Guidelines recommend active surveillance and ablative techniques only in selected patients with stage I (T1a) RCC.

\section{Management of Stage I (pT1b) Disease}

Partial nephrectomy for localized RCC has an oncologic outcome similar to that of radical surgery for T1b tumors. ${ }^{74,75}$ Surgery by partial nephrectomy, whenever feasible, or by radical nephrectomy is the standard of care for clinical T1b tumors according to the NCCN panel.

\section{Management of Stage II and III Disease}

The curative therapy for patients with stages II and III disease remains radical nephrectomy. ${ }^{37}$ Radical nephrectomy is the preferred treatment for the tumors that extend into the inferior vena cava. Resection of a caval or atrial thrombus often requires the assistance of cardiovascular surgeons because treatment-related mortality may reach $10 \%$, depending on the local extent of the primary tumor and the level of vena caval extension. Partial nephrectomy is generally not suitable for patients with locally advanced tumors; however, it may be performed in patients with locally advanced tumors if technically feasible and clinically indicated. For example, partial nephrectomy may be considered for those with small, polar, unilateral tumors.

The NCCN panel lists radical nephrectomy or partial nephrectomy, if feasible or indicated, as options for stage II and III tumors.

\section{Follow-up After Treatment of Localized Disease}

After surgical excision, $20 \%$ to $30 \%$ of patients with localized tumors experience relapse. Lung metastasis is the most common site of distant recurrence, occurring in $50 \%$ to $60 \%$ of patients. The median time to relapse after surgery is 1 to 2 years, with most relapses occurring within 3 years. ${ }^{76}$

The NCCN panel has provided a framework for follow-up of patients undergoing surveillance of a small renal mass and for patients who underwent surgery or ablative therapy of a primary RCC. The NCCN panel has reiterated in a footnote that no single follow-up plan is appropriate for everyone, and follow-up should be modified for the individual patient using clinical judgment. Because there is a lack of uniform consensus among the panel members regarding the most appropriate follow-up plan, these recommendations are listed as category $2 \mathrm{~B}$. Also, the guidance for follow-up has been provided for the first 5 years after nephrectomy, with follow-up evaluation to be extended beyond 5 years at the discretion of the physician. Results from a retrospective analysis indicate that in a subset of patients, relapses occur $>5$ years after surgery for their primary RCC. ${ }^{77}$ The analysis suggests that continued follow-up/surveillance after 5 years may be of potential value in some patients. Identification of subsets of patients with higher risk who require longer follow-up has not been defined, and further research is required to refine follow-up strategies for patients with RCC.

The NCCN Guidelines incorporate a risk-stratified use of imaging that may target those patients most in need of intensive surveillance and/or imaging tests during follow-up.

\section{Follow-up During Active Surveillance for Stage pT1a}

For follow-up during active surveillance, the NCCN panel recommends a history and physical examination 
(H\&P), a comprehensive metabolic panel, and other tests every 6 months for 2 years, then annually for up to 5 years after diagnosis. To study the tumor growth rate, the panel recommends abdominal imaging (with CT or MRI) within 6 months for 2 years from initiation of active surveillance; subsequent imaging (with CT, MRI, or ultrasound) may be performed annually thereafter. All 3 modalities (ultrasound, CT, and MRI) have been found to accurately predict pathologic tumor size in a retrospective analysis. ${ }^{78}$ Therefore, best clinical judgment should be used in choosing the imaging modality. For patients with biopsy results positive for RCC, the recommendation is to annually assess for pulmonary metastases using chest imaging (radiograph or CT). The panel recommends imaging of the pelvis, CT or MRI of the head or spine if there are neurologic symptoms, or bone scan in cases of elevated ALP, bone pain, or abnormal radiologic findings.

\section{Follow-up After Ablative Therapy for Stage pT1a} Most follow-up tests after ablative therapy recommended by the NCCN panel are similar to those recommended during active surveillance. For imaging tests after ablative therapy, the panel recommends abdominal CT or MRI with and without intravenous contrast unless otherwise contraindicated at 3 and 6 months to assess treatment response, followed by annual abdominal CT or MRI scans for 5 years. The panel recommends annual chest radiograph or CT to assess for pulmonary metastases for 5 years in those who have biopsy-proven low-risk RCC, nondiagnostic biopsies, or no prior biopsy to assess liver metastases. The panel suggests repeat biopsy if there is radiographic evidence of progressive increase in size of an ablated neoplasm with or without contrast enhancement, new nodularity in or around the treated zone, failure of the treated lesion to regress over time, or evidence of satellite or port site lesions.

\section{Follow-up After Nephrectomy for Stages I-III}

Adjuvant treatment after nephrectomy currently has no established role in patients who have undergone a complete resection of their tumor. No systemic therapy has yet been shown to reduce the likelihood of relapse. Randomized trials comparing adjuvant interferon alpha (IFN- $\alpha$ ), high-dose interleukin-2 (IL-2), or cytokine combinations versus observation alone in patients who had locally advanced, completely resected RCC showed no delay in time to relapse or improvement in survival with adjuvant therapy ${ }^{79}$ A recently reported multicenter, phase III study (ECOG-ACRIN E2805) in patients with high-grade tumors $\geq \mathrm{T} 1 \mathrm{~b}$ found no survival benefit with use of sunitinib or sorafenib versus placebo as adjuvant therapy after nephrectomy. ${ }^{80}$ Observation remains the standard of care after nephrectomy, and eligible patients should be offered enrollment in randomized clinical trials. Several ongoing and recently completed clinical trials explore the role of targeted therapy in the adjuvant setting. Adjuvant radiotherapy (RT) after nephrectomy has not shown benefit, even in patients with nodal involvement or incomplete tumor resection. For patients with stages pT1a and $\mathrm{pT} 1 \mathrm{~b}$ disease after partial or radical nephrectomy, the NCCN panel recommends H\&P, comprehensive metabolic panel, and other tests every 6 months for 2 years, then annually for up to 5 years after nephrectomy. The panel recommends a baseline abdominal scan (CT, MRI, or ultrasound) for patients undergoing either partial nephrectomy or radical nephrectomy within 3 to 12 months after surgery. If the initial postoperative imaging is negative, abdominal imaging beyond 12 months for patients who have undergone radical nephrectomy may be performed at the discretion of the physician, and for those who have undergone partial nephrectomy, abdominal scans (CT, MRI, or ultrasound) may be considered annually for 3 years based on individual risk factors. The rates of local recurrence for smaller tumors after partial nephrectomy are $1.4 \%$ to $2 \%$ versus $10 \%$ for larger tumors. ${ }^{81-83}$

The panel recommends yearly chest imaging (chest radiograph or CT) for 3 years, then as clinically indicated thereafter, and recommends imaging of the pelvis, CT or MRI of the head and spine, or bone scan performed as clinically indicated.

For patients with stage II-III disease after radical nephrectomy, larger tumors have a substantially higher risk of both local and metastatic recurrence; therefore, an increased frequency of examination is recommended compared with patients with stages pT1a or pT1b. The panel recommends an H\&P every 3 to 6 months for 3 years, then annually for 5 years after surgery. The follow-up evaluation may be extended beyond 5 years at the discretion of the physician as clinically indicated. A comprehensive metabolic panel and other tests are recommended as 
clinically indicated every 6 months for 2 years, then annually for 5 years after surgery, and thereafter as clinically indicated.

The panel recommends baseline chest imaging (with CT) and abdominal scans (CT or MRI) within 3 to 6 months after surgery, with continued imaging (chest CT or chest radiograph; CT, MRI, or ultrasound of the abdomen) every 6 months for at least 3 years, and annually thereafter for up to 5 years after radical nephrectomy. ${ }^{84}$ Although the use of ultrasound imaging for follow-up is an option for low-risk patients, CT is the preferred modality for those with a high risk of recurrence. There is disagreement among the panel members regarding the usefulness of ultrasound in patients with stage III disease; therefore, it is listed as a category $2 \mathrm{~B}$ option specifically for patients with stage II disease. The panel has noted that imaging beyond 5 years may be performed as clinically indicated, and site-specific imaging may be performed as symptoms warrant. Other tests, such as imaging of the pelvis, CT or MRI of the head or spine, and bone scan, are recommended as clinically indicated.

Alternate surveillance programs have been proposed, such as the surveillance protocol based on the UCLA Integrated Staging System (UISS). ${ }^{85}$ The UISS is an evidence-based system in which patients are stratified based on the 1997 TNM stage, grade, and ECOG performance status into low-, intermediate-, or high-risk groups for developing recurrence or metastases after surgical treatment of localized or locally advanced RCC. ${ }^{86}$

\section{Management of Advanced or Stage IV Disease}

Patients with stage IV disease also may benefit from surgery. For example, lymph nodes suspicious for metastatic disease on CT may be hyperplastic and not involved with tumor; thus, the presence of minimal regional adenopathy does not preclude surgery. In addition, the small subset of patients with potentially surgically resectable primary RCC and a solitary resectable metastatic site are candidates for nephrectomy and surgical metastasectomy. Candidates include patients who initially present with primary RCC and a solitary site of metastasis, or those who develop a solitary recurrence after a prolonged disease-free interval from nephrectomy. Sites of solitary metastases that are amenable to this approach include the lung, bone, and brain. The primary tumor and metastasis may be resected during the same operation or at different times. Most patients who undergo resection of a solitary metastasis experience recurrence, but long-term PFS has been reported in these patients.

\section{Prognostic Models}

Prognostic scoring systems have been developed to define risk groups of patients by combining independent prognostic factors for survival in patients with metastatic RCC.

The most widely used prognostic factor model is from Memorial Sloan Kettering Cancer Center (MSKCC). The model was derived from examining prognostic factors in patients $(n=463)$ with metastatic RCC enrolled in clinical trials and treated with IFN. ${ }^{86}$ Prognostic factors for multivariable analysis included 5 variables: interval from diagnosis to treatment of $<1$ year; Karnofsky performance status $<80 \%$; serum lactate dehydrogenase $(\mathrm{LDH})$ $>1.5$ times the upper limit of normal (ULN); corrected serum calcium greater than the ULN; and serum hemoglobin less than the lower limit of normal (LLN). Patients with none of these factors are considered low risk or with good prognosis, those with 1 or 2 factors are considered intermediate risk, and those with $\geq 3$ factors are considered poor risk. The MSKCC criteria have been additionally validated by an independent group at the Cleveland Clinic. ${ }^{87}$

A prognostic model derived from a population of patients with metastatic RCC treated with vascular endothelial growth factor (VEGF)-targeted therapy has been developed, and is known as the International Metastatic RCC Database Consortium, or the Heng model. ${ }^{88}$ This model was derived from a retrospective study of 645 patients with metastatic RCC treated with sunitinib, sorafenib, or bevacizumab plus interferon. Patients who received prior immunotherapy (ie, received their targeted therapy as second-line treatment) were also included in the analysis. The analysis identified 6 clinical parameters to stratify patients into favorable, intermediate, and poor prognosis groups; 4 of the 5 adverse prognostic factors are those previously identified by MSKCC as independent predictors of short survival: hemoglobin less than the LLN, serum corrected calcium greater than the ULN, Karnofsky performance status 
$<80 \%$, and time from initial diagnosis to initiation of therapy of $<1$ year. Additional, independent, adverse prognostic factors validated in this model are absolute neutrophil count greater than ULN and platelets greater than ULN..$^{88}$

Patients with none of the identified 6 adverse factors were in the favorable-risk category $(n=133$; $22.7 \%$ ) in which a median OS was not reached and 2 -year OS was 75\% (95\% CI, 65\%-82\%). Patients with 1 or 2 adverse factors were in the intermediaterisk category $(\mathrm{n}=301 ; 51.4 \%)$ in which a median OS was 27 months and a 2-year OS rate was 53\% (95\% CI, 46\%-59\%). Finally, patients with 3 to 6 adverse factors were in the poor-risk category $(n=152 ; 25.9 \%)$ in which a median OS was 8.8 months and a 2 -year OS rate was $7 \%$ (95\% CI, 2\%-16\%)..$^{88}$ This model was recently validated in an independent data set. ${ }^{89}$

\section{Primary Treatment of Relapsed or Stage IV Disease and Surgically Unresectable Disease}

Cytoreductive nephrectomy before systemic therapy is generally recommended in patients with a potentially surgically resectable primary tumor mass. Randomized trials showed a benefit of cytoreductive nephrectomy in patients who received IFN- $\alpha$ therapy after surgery. In similar phase III trials, the SWOG and EORTC randomized patients with metastatic disease to undergo either nephrectomy followed by IFN- $\alpha$ therapy or treatment with IFN- $\alpha$ alone. ${ }^{90-92} \mathrm{~A}$ combined analysis of these trials showed that median survival favored the surgery plus IFN- $\alpha$ group (13.6 vs 7.8 months for IFN- $\alpha$ alone) ${ }^{90-93}$

Patient selection is important to identify those who might benefit from cytoreductive therapy. Those most likely to benefit from cytoreductive nephrectomy before systemic therapy have lung-only metastases, good prognostic features, and good performance status. ${ }^{94}$ Although similar data are not available for patients who are candidates for high-dose IL-2 (see later discussion), data from the UCLA renal cancer database and from a variety of publications by other groups suggest that nephrectomy also provides benefit to patients who undergo other forms of immunotherapy. ${ }^{95}$ As for the role of nephrectomy for patients presenting with metastatic disease and considered for targeted therapies (detailed later), randomized trials are ongoing at this time, but data from the
International Metastatic RCC Database Consortium suggest that cytoreductive nephrectomy continues to play a role in patients treated with VEGF-targeted agents. ${ }^{96}$ Patients with metastatic disease who present with hematuria or other symptoms related to the primary tumor should be offered palliative nephrectomy if they are surgical candidates. In those whose tumors are surgically unresectable, the NCCN panel recommends performing tissue sampling to confirm diagnosis of RCC and determine histology and guide subsequent management.

\section{First-line Therapy for Patients With Predominantly Clear Cell Carcinoma}

\section{Cytokine Therapy}

Until late 2005, systemic treatment options for metastatic RCC were limited to cytokine therapy and clinical trials of novel agents. For patients with metastatic, recurrent, or unresectable clear cell RCC, various combinations and dosages of IL-2 and IFN were studied in randomized trials. IL-2 was shown to have potent antitumor activity first in several murine tumor models ${ }^{97}$ and subsequently in patients with RCC. ${ }^{98-100}$ With both IFN- $\alpha$ and IL-2, objective response rates of $5 \%$ to $27 \%$ have been reported. ${ }^{100-102}$ Although these agents have been helpful for some patients, in most cases the clinical benefit is modest at best and is achieved at the expense of significant toxicity.

High-Dose IL-2 as First-Line Therapy for Predominantly Clear Cell Carcinoma: IL-2-based immunotherapy is reported to achieve long-lasting complete or partial remissions in a small subset of patients. In patients treated with IFN- $\alpha$, durable complete responses are rare. Although direct comparison has not been performed of IFN- $\alpha$ and high-dose intravenous bolus IL-2 as approved by the FDA and used in US centers, data from a French multicenter study suggested similar outcomes from IFN- $\alpha$ or infusional IL-2, with superior responses at the cost of higher toxicity reported in the combination therapy group. High-dose IL-2 is associated with substantial toxicity, and to date attempts to characterize tumor or patient factors for best response to this therapy have been unsuccessful. ${ }^{97,101,103}$ Thus, the best criteria to select patients for IL-2 therapy are based largely on safety and include the patient's performance status, medical comorbidities, tumor histology (predominantly clear cell), MSKCC or Survival After Nephrectomy 
and Immunotherapy (SANI) risk scores, ${ }^{86,95,104}$ and the patient's attitude toward risk.

For highly selected patients with relapsed or medically unresectable stage IV clear cell renal carcinoma, the NCCN panel lists high-dose IL-2 as a first-line treatment option with a category $2 \mathrm{~A}$ designation.

\section{Targeted Therapy}

Targeted therapy using tyrosine kinase inhibitors (TKIs) and anti-VEGF antibodies is widely used in first- and second-line treatments. To date, 7 such agents have been approved by the FDA for the treatment of advanced RCC: sunitinib, sorafenib, pazopanib, axitinib, temsirolimus, everolimus, and bevacizumab in combination with interferon.

Tumor histology and risk stratification of patients is important in targeted therapy selection. The histologic diagnosis of RCC is established after surgical removal of renal tumors or after biopsy. According to the WHO, the 3 most common histologic RCC types are clear cell RCC, papillary RCC, and chromophobe RCC. ${ }^{30}$ Prognostic systems are used for risk stratification in the metastatic setting. ${ }^{86,88}$

Pazopanib as First-line Therapy for Predominantly Clear Cell Carcinoma: Pazopanib is an oral angiogenesis inhibitor targeting VEGFR-1, -2, and -3 , PDGFR $-\alpha$ and $-\beta$, and c-KIT. The safety and effectiveness of pazopanib was evaluated in a phase III, open-label, international, multicenter study. A total of 435 patients with clear cell advanced RCC and measurable disease with no prior treatment or 1 prior cytokine-based treatment were randomized 2:1 to pazopanib or placebo. PFS was prolonged significantly with pazopanib in the overall study population, averaging 9.2 versus 4.2 months for patients assigned to placebo. ${ }^{105}$ The treatment-naive subpopulation of 233 patients, randomized 2:1 to pazopanib versus placebo, had a median PFS of 11.1 months on pazopanib versus 2.8 months on placebo. ${ }^{105}$ The objective response rate was 30\% with pazopanib and $3 \%$ with placebo (all results were statistically significant). Common adverse reactions to pazopanib (any grade) included diarrhea (52\%), hypertension (40\%), hair color changes, nausea (26\%), anorexia $(22 \%)$, vomiting $(21 \%)$, fatigue $(19 \%)$, weakness $(14 \%)$, abdominal pain $(11 \%)$, and headache (10\%). Notable grade 3 toxicity was hepatotoxicity, indicated by elevated levels of alanine (30\%) and aspartate $(21 \%)$ transaminase. Therefore, it is critical to monitor liver function before and during treatment with the drug.

The final analysis of OS and updated safety results of pazopanib did not show a statistically significant effect on OS. ${ }^{106}$ The lack of correlation between OS and PFS is attributed to the extensive crossover of placebo-treated patients to pazopanib via the parallel open-label extension, as well as other subsequent anticancer treatments that patients from both arms received after progression. ${ }^{106}$ In the updated analyses, ${ }^{106}$ no differences in the frequency or severity of adverse events or grade $3 / 4$ adverse events were seen compared with the previous report. ${ }^{105}$

Results of a large noninferiority study (COMPARZ) of sunitinib versus pazopanib showed that these 2 drugs have a similar efficacy profile and a differentiated safety profile. ${ }^{107}$ Among 1,110 patients with clear cell metastatic RCC who were randomized to receive pazopanib or sunitinib, those receiving pazopanib achieved a median PFS of 8.4 months compared with 9.5 months for those receiving sunitinib (hazard ratio [HR], 1.047). Overall response rates (ORRs) were $31 \%$ for pazopanib and $25 \%$ for sunitinib. Pazopanib was associated with less fatigue than sunitinib ( $55 \%$ vs $63 \%$, respectively), less hand-foot syndrome ( $29 \%$ vs $50 \%$, respectively), less alteration in taste (26\% vs 36\%, respectively), and less thrombocytopenia ( $10 \%$ vs $34 \%$, respectively). However, pazopanib was associated with more transaminase elevation than sunitinib (31\% vs $18 \%$, respectively). ${ }^{107}$ The results of the final OS analysis were similar in the 2 groups (HR for death with pazopanib vs sunitinib, 0.92; $95 \% \mathrm{CI}$, $0.79-1.06) .{ }^{108}$ Median OS was 28.3 months in the pazopanib group (95\% CI, 26.0-35.5) and 29.1 months in the sunitinib group (95\% CI, 25.4-33.1). A subgroup analysis was performed based on risk status. In patients with favorable-risk disease, a median OS was 42.5 months for those receiving pazopanib versus 43.6 months for those receiving sunitinib. Among patients with intermediate-risk disease, the median OS was 26.9 months for those who received pazopanib versus 26.1 months for those who received sunitinib. Among patients with poor-risk disease, the median OS was 9.9 months for those who received pazopanib and 7.7 months for those who received sunitinib. ${ }^{108}$

The results of the COMPARZ trial ${ }^{107,108}$ are supported by those of another smaller phase III study (PISCES). ${ }^{109}$ In the PISCES trial, 168 patients were 
blinded and randomized in a 1:1 manner to first-line $800 \mathrm{mg}$ of pazopanib for 10 weeks followed by a 2 -week break (placebo) and then $50 \mathrm{mg}$ of sunitinib for 10 weeks ( 4 weeks on and 2 weeks off schedule) or vice versa. ${ }^{109}$ The primary end point was patient preference, assessed at 22 weeks. When asked about preference of one drug over another, approximately $70 \%$ preferred pazopanib due to better quality of life (QOL), compared with $22 \%$ choosing sunitinib and the remaining $8 \%$ having no preference. Approximately $50 \%$ of the patients on pazopanib reported less fatigue compared with about $15 \%$ of patients on sunitinib, and approximately $45 \%$ of patients on pazopanib reported fewer changes in food taste with the drug compared with about $10 \%$ of patients on sunitinib. ${ }^{109}$

The NCCN panel has listed pazopanib as a preferred category 1 option for first-line treatment of patients with relapsed or medically unresectable predominantly clear cell stage IV renal carcinoma.

\section{Sunitinib as First-line Therapy for Predominantly} Clear Cell Carcinoma: Sunitinib is a multikinase inhibitor targeting several receptor tyrosine kinases, including platelet-derived growth factor receptors (PDGFR- $\alpha$ and $-\beta$ ), VEGF receptors (VEGFR-1, -2 , and -3), stem cell factor receptor (c-KIT), FMSlike tyrosine kinase (FLT-3), colony-stimulating factor (CSF-1R), and neurotrophic factor receptor (RET). ${ }^{110,111}$

Preclinical data suggested that sunitinib has antitumor activity that may result from both inhibition of angiogenesis and inhibition of cell proliferation. ${ }^{112,113}$ After promising phase I and II data, the efficacy of sunitinib in previously untreated patients with metastatic RCC was studied in a large multinational phase III trial in which 750 patients with metastatic (all risk) clear cell histology RCC were randomized 1:1 to receive either sunitinib or IFN- $\alpha .{ }^{110}$ The patients selected for the trial had no prior treatment with systemic therapy, good performance status, and measurable disease. The primary end point was PFS and secondary end points were patient-related outcomes, OS, response rate, and safety. The treatment arms were well balanced; patients had a median age of 60 years, and 90\% had undergone prior nephrectomy. Approximately 90\% of patients in the trial had either "favorable" or "intermediate" MSKCC risk features. The median PFS was 11 months for the sunitinib arm and 5 months for the IFN- $\alpha$ arm. The objective response rate assessed by independent review was $31 \%$ for the sunitinib arm versus $6 \%$ for the IFN- $\alpha$ arm. Severe adverse events (grade 3-4 toxicities) were acceptable, with neutropenia (12\%), thrombocytopenia $(8 \%)$, hyperamylasemia $(5 \%)$, diarrhea $(5 \%)$, handfoot syndrome (5\%), and hypertension (8\%) being noteworthy in the sunitinib arm and fatigue being more common with IFN- $\alpha$ (12\% vs $7 \%)$. Updated results demonstrate a strong trend toward an OS advantage of sunitinib over IFN- $\alpha$ in the first-line setting (26.4 vs 21.81 months; $P=.051) .{ }^{102}$ Results from an expanded access trial revealed that sunitinib possesses an acceptable safety profile and has activity in subgroups of patients with brain metastases, nonclear cell histology, and poor performance status. ${ }^{114}$

A retrospective study using the International metastatic RCC database consortium studied the efficacy of first-line treatment with sunitinib compared with pazopanib at the population-based level. No difference in OS was seen between the treatment options (22.3 vs 22.6 months, respectively; $P=.65$ ), ${ }^{115}$ nor was any difference observed in PFS and response rates between the options. ${ }^{115}$

Based on these studies and its tolerability, the NCCN panel has also listed sunitinib as a preferred category 1 option for first-line treatment of patients with relapsed or medically unresectable predominantly clear cell stage IV renal carcinoma.

Bevacizumab Along With Interferon as First-line Therapy for Predominantly Clear Cell Carcinoma: Bevacizumab is a recombinant humanized monoclonal antibody that binds and neutralizes circulating VEGF-A. In a multicenter randomized, double-blind phase III trial (AVOREN) compared bevacizumab plus IFN- $\alpha$ versus placebo plus IFN- $\alpha$ in 649 patients (641 treated), ${ }^{116}$ the addition of bevacizumab to IFN- $\alpha$ significantly increased PFS (10.2 vs 5.4 months) and objective tumor response rate $(30.6 \%$ vs $12.4 \%)$. No significant increase or novel adverse effects were observed with the combination over IFN- $\alpha$ alone. A trend toward improved OS was also observed (23.3 months with bevacizumab plus IFN- $\alpha$ vs 21.3 months for IFN- $\alpha$ ), although the difference did not reach statistical significance. ${ }^{116}$

In the United States, a similar trial was performed by the CALGB, with 732 previously untreated patients randomized 1:1 to receive either IFN- $\alpha$ or the combination of bevacizumab plus IFN- $\alpha$. Bevacizumab plus IFN $-\alpha$ produced a superior PFS (8.5 vs 5.2 
months) and higher objective response rate (25.5\% vs $13.1 \%)$ compared with IFN- $\alpha$ alone. However, toxicity was greater in the combination therapy arm. ${ }^{117} \mathrm{No}$ significant differences in median survival were seen between the groups (18.3 vs 17.4 months for bevacizumab plus IFN- $\alpha$ vs IFN- $\alpha$ alone). ${ }^{118}$

The NCCN panel recommends bevacizumab in combination with IFN- $\alpha$ as a category 1 option for first-line treatment of patients with relapsed or medically unresectable predominantly clear cell stage IV renal carcinoma.

Temsirolimus as First-line Therapy for Predominantly Clear Cell Carcinoma: Temsirolimus is an inhibitor of the mTOR protein, which regulates micronutrients, cell growth, apoptosis, and angiogenesis through its downstream effects on a variety of proteins. Efficacy and safety of temsirolimus were demonstrated at a second interim analysis of the ARCC trial, a phase III, multicenter, randomized, open-label study in previously untreated patients with advanced RCC who had $\geq 3$ of 6 unfavorable prognostic factors. ${ }^{119}$ The prognostic factors included: $<1$ year from the time of diagnosis to start of systemic therapy, Karnofsky performance status score of 60 to 70 , hemoglobin less than the LLN, corrected calcium level $>10 \mathrm{mg} / \mathrm{dL}$, $\mathrm{LDH}$ greater than 1.5 times the ULN, and metastasis to $\geq 1$ organ site. A total of 626 patients were randomized equally to receive IFN- $\alpha$ alone, temsirolimus alone, or the combination of temsirolimus and IFN- $\alpha$. Premedication with an antihistamine was recommended to patients in both temsirolimus-containing groups to prevent infusion reactions. Patients were stratified for prior nephrectomy and geographic region; $70 \%$ were $<65$ years of age and $69 \%$ were male. The group of patients who received temsirolimus alone showed a significant improvement in OS compared with those receiving IFN- $\alpha$ alone or both drugs. The median OS was 10.9 months for patients on temsirolimus alone versus 7.3 months for those treated with IFN- $\alpha$ alone. The median PFS (the study's secondary end point) increased from 3.1 months with IFN- $\alpha$ alone to 5.5 months with temsirolimus alone. The combination of temsirolimus and IFN- $\alpha$ not only failed to improve OS or PFS but also led to an increase in multiple adverse reactions, including grade 3 or 4 rash, stomatitis, pain, infection, peripheral edema, thrombocytopenia and neutropenia, hyperlipidemia, hypercholesteremia, or hyperglycemia.
Based on these data, the NCCN panel has included temsirolimus as a category 1 recommendation for first-line treatment of poor-risk patients with relapsed or medically unresectable predominantly clear cell stage IV renal carcinoma.

Sorafenib as First-Line Therapy for Predominantly Clear Cell Carcinoma: Sorafenib tosylate is a small molecule that inhibits multiple isoforms of the intracellular serine/threonine kinase, RAF, and also other receptor tyrosine kinases, including VEGFR-1, -2, and -3 , PDGFR- $\beta$, FLT-3, $c-$ KIT, and RET. ${ }^{120-124}$

A phase II trial investigating the efficacy and safety of sorafenib versus IFN- $\alpha$ in previously untreated patients with clear cell $\mathrm{RCC}^{125}$ randomized $189 \mathrm{pa}$ tients to receive continuous oral sorafenib $(400 \mathrm{mg}$ twice daily) or IFN- $\alpha$, with an option of dose escalation of sorafenib to $600 \mathrm{mg}$ twice daily or crossover from IFN- $\alpha$ to sorafenib (400 $\mathrm{mg}$ twice daily) on disease progression. The primary end point was PFS. In the IFN- $\alpha$ arm, 90 patients received treatment; 56 had disease progression, 50 of whom crossed over to sorafenib (400 mg twice daily). In the sorafenib arm, 97 patients received treatment and had a median PFS of 5.7 months compared with 5.6 months for IFN- $\alpha$. The results showed that more sorafenibtreated $(68.2 \%$ vs $39.0 \%)$ patients had tumor regression. ${ }^{125}$ Overall, the incidence of adverse events was similar between both treatment arms, although skin toxicity (rash and hand-foot skin reaction) and diarrhea occurred more frequently in patients treated with sorafenib, and flu-like syndrome occurred more frequently in the IFN- $\alpha$ group. Sorafenib-treated patients reported fewer symptoms and better quality of life (QOL) than those treated with IFN- $\alpha$. Both dose escalation of sorafenib after progression and a switch to sorafenib after progression on IFN- $\alpha$ resulted in progression-free intervals that suggested a clinical benefit of sorafenib (as second-line therapy) after first-line treatment with IFN- $\alpha$ and in those who had been treated with sorafenib up front.

The NCCN panel lists sorafenib as a category 2A option as first-line treatment for selected patients with relapsed or medically unresectable stage IV predominantly clear cell RCC.

Axitinib as First-Line Therapy for Predominantly Clear Cell Carcinoma: As second-line therapy for patients with predominantly clear cell carcinoma, treatment with axitinib has clearly demonstrated 
greater objective response and longer median PFS compared with those treated with sorafenib. To determine whether this holds true in the first-line setting, a randomized, open-label, phase III trial was conducted in newly diagnosed patients randomized $(2: 1)$ to receive axitinib ( $5 \mathrm{mg}$ twice daily) or sorafenib (400 mg twice daily). ${ }^{126}$ The median PFS seen in patients treated with axitinib was 10.1 months (95\% CI, 7.2-12.1) and for those treated with sorafenib was 6.5 months (95\% CI, 4.7-8.3). ${ }^{126}$ The adverse events more commonly seen with axitinib ( $\geq 10 \%$ difference) than with sorafenib treatment were diarrhea, hypertension, weight loss, decreased appetite, dysphonia, hypothyroidism, and upper abdominal pain; adverse events more commonly seen with sorafenib treatment included palmar-plantar erythrodysesthesia, rash, alopecia, and erythema. ${ }^{126}$ The difference in PFS between patients treated with axitinib versus sorafenib is not statistically significant; however, the results demonstrated clinical activity of axitinib with acceptable toxicity profile in the first-line setting.

Another randomized, multicenter, phase II trial evaluated the efficacy and safety of axitinib dose titration in newly diagnosed patients with metastatic RCC. ${ }^{127}$ In this study, all patients received axitinib, $5 \mathrm{mg}$ twice daily for 4 weeks, and then were assigned (1:1) to placebo titration or axitinib twice-daily dose titrated stepwise to $7 \mathrm{mg}$ and if this was tolerated, up to a maximum of $10 \mathrm{mg} / \mathrm{d}$. More patients in the axitinib titration group achieved an objective response compared with the placebo group (54\% vs 34\%).

Based on these results, the NCCN panel included axitinib as a first-line treatment option (category 2A).

\section{Subsequent Therapy for Patients with Predominantly Clear Cell Carcinoma}

Cabozantinib: Cabozantinib is a small molecule inhibitor of tyrosine kinases such as VEGF receptors, MET, and AXL. It is FDA-approved for patients with progressive medullary thyroid cancer. A phase III trial (METEOR) randomized 658 patients with disease progression after previous TKI therapy to receive $60 \mathrm{mg} / \mathrm{d}$ of oral cabozantinib $(\mathrm{n}=331)$ or 10 $\mathrm{mg} / \mathrm{d}$ of oral everolimus $(\mathrm{n}=321) .{ }^{128}$ The estimated median PFS for patients randomized to cabozantinib was 7.4 months versus 3.8 months for everolimus (HR, 0.58; 95\% CI, 0.45-0.75; P<.001). The objec- tive response rate was $21 \%$ for cabozantinib and $5 \%$ for everolimus $(P<.001){ }^{128}$

The final analysis of the METEOR trial shows a statistically significant increase in OS in the cabozantinib arm, ${ }^{129}$ with a median OS of 21.4 months for patients treated with cabozantinib versus 16.5 months for those treated with everolimus (HR, 0.66; 95\% CI, 0.53-0.83; P=.00026). ${ }^{129}$

An independent review has confirmed that cabozantinib treatment also resulted in improved PFS (HR, 0.51; 95\% CI, 0.41-0.62; P<.0001) and a statistically significant increase in the objective response rate $(17 \%$ vs $3 \% ; \mathrm{P}<.001) .{ }^{129}$

The most commonly reported grade 3 or 4 treatment-related adverse effects associated with cabozantinib were hypertension, diarrhea, and fatigue, and for everolimus were anemia, fatigue, and hyperglycemia. The rate of treatment discontinuation due to adverse effects of the treatment was similar in both arms (9\% with cabozantinib arm vs $10 \%$ with everolimus). The longer PFS and increased OS with cabozantinib when compared with everolimus makes cabozantinib a preferred choice in the second-line setting for advanced RCC.

Based on the METEOR trial results, ${ }^{128,129}$ the NCCN panel has included cabozantinib as a category 1 preferred subsequent therapy option.

Nivolumab: Nivolumab is an antibody that selectively blocks the interaction between PD-1 (expressed on activated $T$ cells) and its ligands (expressed on immune cells and tumor cells). In a phase III trial (CheckMate 025), patients ( $N=821)$ with advanced clear cell $\mathrm{RCC}$, previously treated with $\geq 1$ lines of therapy (excluding mTOR), were randomly assigned (in a 1:1 ratio) to receive nivolumab ( $3 \mathrm{mg} / \mathrm{kg}$ body weight) intravenously every 2 weeks or everolimus, $10 \mathrm{mg} / \mathrm{d}$ orally. ${ }^{130}$ The primary end point of the trial was OS. The median OS was 5.4 months longer with nivolumab compared with everolimus (25.0 vs 19.6 months). The HR for death (from any cause) was 0.73 with nivolumab versus everolimus $(P=.002)$. The ORR was also reported to be 5 times greater with nivolumab ( $25 \%$ vs 5\%; odds ratio, 5.98; 95\% CI, 3.68- 9.72; $\mathrm{P}<.001) .{ }^{130}$

Treatment-related adverse events of any grade were seen in $79 \%$ of those who received nivolumab and $88 \%$ of those who received everolimus; grade $3 / 4$ events occurred in $19 \%$ and $37 \%$, respectively. The most common grade $3 / 4$ events were fatigue $(2 \%)$ with nivolumab and anemia (8\%) with everolimus. 
Toxicities led to treatment discontinuations in $8 \%$ and $13 \%$ of patients, respectively. Two deaths were reported in the everolimus arm, and there were no treatment-related deaths in the nivolumab arm. ${ }^{130}$

An independent analysis was performed to determine the efficacy of nivolumab-based baseline factors, such as Karnofsky performance status, Heng risk group, number of prior therapies, and specific prior therapies (ie, sunitinib, pazopanib, IL-2). A consistent OS benefit and ORR was observed across all baseline factors. ${ }^{131}$

The FKSI-DRS ${ }^{132}$ questionnaire was used to obtain a QOL score for patients enrolled in the trial. The median change from baseline in the FKSI-DRS score in the nivolumab group increased over time, suggesting a significant and consistent improvement in QOL of patients in this group. ${ }^{130}$ Because of the OS advantage shown over everolimus in the secondline setting, nivolumab is preferred for advanced RCC after an antiangiogenic agent.

Because immunotherapy response patterns differ from traditional systemic therapies, the effect of continuing treatment with nivolumab was retrospectively reviewed in patients enrolled in the CheckMate 025 trial who had disease progression on nivolumab treatment. Results showed that nivolumab treatment beyond first progression was associated with reduced tumor burden in approximately $50 \%$ of patients with advanced RCC and $14 \%$ achieved $\geq 30 \%$ reduction in tumor burden. ${ }^{133}$ It should be noted that patients treated with nivolumab after progression generally had more favorable disease characteristics than those who discontinued treatment after first progression. ${ }^{133}$ In patients receiving nivolumab after progression, adverse events (any grade) occurred less frequently after progression versus before progression. These data suggest that a subset of patients benefit from treatment beyond progression, but this approach needs to be prospectively validated. ${ }^{133}$

Based on the results of the CheckMate $025^{130}$ trial demonstrating superior $\mathrm{OS}$ with nivolumab compared with everolimus, the NCCN panel included nivolumab as a category 1 , preferred subsequent therapy option

Lenvatinib With Everolimus as Subsequent Therapy for Predominantly Clear Cell Carcinoma: Lenvatinib is a multitargeted TKI initially developed for use in differentiated thyroid carcinoma that is refractory to standard therapy.
In a phase II trial, 153 patients with metastatic or unresectable, locally advanced, clear cell RCC who had received prior antiangiogenic therapy were randomly assigned to lenvatinib plus everolimus or single-agent lenvatinib or single-agent everolimus. ${ }^{134}$ Compared with everolimus monotherapy, lenvatinib plus everolimus showed significantly prolonged PFS (median, 14.6 vs 5.5 months; HR, 0.40; 95\% CI, $0.24-0.68)^{134}$ and increased median OS (25.5 vs 15.4 months; HR, 0.67: 0.42-1.08). ${ }^{135}$ Median OS for lenvatinib alone was 18.4 months. ${ }^{135}$

Lenvatinib plus everolimus is listed as a category 1 recommendation for subsequent therapy by the NCCN panel.

Axitinib as Subsequent Therapy for Predominantly Clear Cell Carcinoma: Axitinib is a selective, second-generation inhibitor of VEGFR-1, -2, and -3. ${ }^{136}$ A multicenter, randomized phase III study (AXIS) compared axitinib versus sorafenib as second-line therapy after 1 prior systemic therapy (with mostly cytokines or sunitinib). ${ }^{137}$ Patients $(n=723)$ were stratified by performance status and type of prior therapy and randomized 1:1 to axitinib (5 mg twice daily) or sorafenib (400 mg twice daily). ${ }^{137}$ The overall median PFS was 6.7 months for axitinib versus 4.7 months for sorafenib (HR, 0.665; $P<.0001)$, and the response rate was $19 \%$ versus $9 \%$, respectively $(P=.0001)$. The PFS favored axitinib in both groups treated with a prior cytokine (12.1 vs 6.5 months; $P<.0001)$ and prior sunitinib (4.8 vs 3.4 months; $P=.01) .{ }^{137}$ Adverse events of all grades more frequent with axitinib were hypertension, fatigue, dysphonia, and hypothyroidism, whereas adverse events more frequent with sorafenib were hand-foot syndrome, rash, alopecia, and anemia.

In the recently reported updated results of the same trial, median OS was 20.1 months (95\% CI, 16.7-23.4) with axitinib and 19.2 months (17.522.3) with sorafenib (HR, 0.969; 95\% CI, 0.8001.174). ${ }^{138}$ Although OS did not significantly differ between the groups, median investigator-assessed PFS was longer with axitinib; PFS was 8.3 months (95\% CI, 6.7-9.2) versus 5.7 months (4.7-6.5) with sorafenib (HR, 0.656; 95\% CI, 0.552-0.779). ${ }^{138}$ The patient-reported outcomes were comparable for second-line axitinib and sorafenib. ${ }^{132}$

In a phase II study of patients with cytokine-refractory metastatic RCC, the 5-year survival rate after 
treatment with axitinib was $20.6 \%$ (95\% CI, 10.9\%$32.4 \%)$, with a median follow-up of 5.9 years. ${ }^{139}$

Axitinib is listed as a category 1 recommendation as a subsequent therapy option by the NCCN panel.

Everolimus as Subsequent Therapy for Predominantly Clear Cell Carcinoma: Everolimus (RAD001) is an orally administered inhibitor of mTOR. In the RECORD 1 trial, an international, multicenter, double-blind, randomized phase III trial, everolimus was compared with placebo for the treatment of metastatic RCC in patients whose disease had progressed on treatment with sunitinib or sorafenib. ${ }^{140} \mathrm{~A}$ total of 410 patients were randomly assigned 2:1 to receive either everolimus or placebo, and the primary end point was PFS. The median PFS assessed by an independent review committee was in favor of everolimus, 4.0 versus 1.9 months. ${ }^{140}$ The most common adverse events reported in patients on everolimus (mostly of mild or moderate severity) versus patients in the placebo group were stomatitis in $40 \%$ versus $8 \%$, rash in $25 \%$ versus $4 \%$, and fatigue in $20 \%$ versus $16 \% .{ }^{140}$ According to the updated results of this trial, median PFS determined by independent central review was 4.9 months for everolimus versus 1.9 months for placebo (95\% CI, 1.8-1.9). ${ }^{141}$

Everolimus is listed as a category 2A subsequent therapy option in the NCCN Guidelines. It is important to note that 2 recent randomized phase III trials (discussed earlier) compared the efficacy of everolimus with nivolumab and cabozantinib. The results of the CheckMate $025^{130}$ trial demonstrated superior OS with nivolumab compared with everolimus. The METEOR trial ${ }^{130}$ demonstrated longer PFS and OS with cabozantinib compared with everolimus. Based on the results of these 2 phase III trials, eligible patients should preferentially receive either nivolumab or cabozantinib over everolimus.

Sorafenib as Subsequent Therapy for Predominantly Clear Cell Carcinoma: Efficacy of sorafenib was studied in 903 patients whose disease progressed on a prior therapy (mostly cytokines) in a phase III, placebo-controlled, randomized trial, TARGET. ${ }^{142,143}$ The patients selected had measurable disease, clear cell histology, one prior systemic therapy in the last 8 months, an ECOG performance status of 0 to 1 , and a good or intermediate prognosis. Almost all patients had undergone nephrectomy. The primary end point of the trial was to assess OS and the secondary end point was to assess PFS.

An interim analysis conducted via independent assessment reported that sorafenib-treated patients had significantly higher PFS than those treated with placebo (5.5 vs 2.8 months, respectively; HR, 0.44; $95 \% \mathrm{CI}, 0.35-0.55 ; P=.000001) .{ }^{143}$ With the large difference in PFS, crossover to the sorafenib treatment arm was recommended, which likely resulted in the failure of this trial to demonstrate an OS benefit for sorafenib in the final analysis. With censoring of crossover data, treatment with sorafenib was found to be associated with improved survival compared with placebo (17.8 vs 14.3 months; HR, 0.78; 95\% CI, 0.62-0.97; $P=.0287) .{ }^{143}$ Common grade $3 / 4$ adverse effects reported more in the sorafenib group than the placebo group were hand-foot syndrome, fatigue, and hypertension. ${ }^{143}$ This study showed the effectiveness of sorafenib was primarily in patients whose disease progressed on prior cytokine therapy. Sorafenib has also been studied as second-line therapy in patients treated with sunitinib or bevacizumab and has been found to be safe, feasible, and effective. ${ }^{144,145}$ Sorafenib is listed as a category 2A subsequent therapy option.

Sunitinib as Subsequent Therapy for Predominantly Clear Cell Carcinoma: Sunitinib also has demonstrated substantial antitumor activity in the second-line therapy of metastatic RCC after progression on cytokine therapy. ${ }^{111,146}$ Studies investigating the sequential use of sunitinib and sorafenib mostly are retrospective. There are prospective data, although limited, that suggest a lack of total cross resistance between TKIs, either sorafenib followed by sunitinib failures or vice versa-an observation that is consistent with their differences in target specificities and slightly different toxicity spectra that sometimes permit tolerance of one agent over another. ${ }^{147-151}$ Sunitinib is considered a category $2 \mathrm{~A}$ subsequent therapy option.

Pazopanib as Subsequent Therapy for Predominantly Clear Cell Carcinoma: The phase III trial comparing pazopanib with placebo, detailed earlier in "Pazopanib as First-line Therapy for Predominantly Clear Cell Carcinoma" (page 819) included 202 patients who received prior cytokine therapy. The average PFS in cytokine pretreated patients was 7.4 versus 4.2 months. ${ }^{105}$

A prospective phase II trial examined the activity and toxicity of second-line treatment with 
pazopanib ( $800 \mathrm{mg} / \mathrm{d}$ orally) in 56 patients with advanced metastatic RCC previously treated with a targeted agent. ${ }^{152}$ The patients enrolled in this trial had previously received first-line treatment with sunitinib $(n=39)$ or bevacizumab $(n=16)$. Responses were evaluated after 8 weeks of treatment using RECIST. The trial showed that $27 \%$ of patients $(n=15)$ had objective response to pazopanib, and $49 \%(n=27)$ had stable disease. ${ }^{152}$ After a median follow-up of 16.7 months, the median PFS was 7.5 months (95\% CI, 5.4-9.4 months). ${ }^{152}$ The PFS was similar whether previous treatment was with sunitinib or bevacizumab. The estimated OS rate at 24 months was $43 \% .{ }^{152}$

Another retrospective analysis reported data on 93 patients with metastatic RCC treated with multiple lines of prior targeted therapies. ${ }^{153}$ Among evaluable patients $(n=85)$ in this study, $15 \%(n=13)$ had a partial response and the median PFS observed was 6.5 months (95\% CI, 4.5-9.7).

Based on these data, the NCCN panel considers pazopanib a category $2 \mathrm{~A}$ subsequent therapy option.

Other Agents as Subsequent Therapy for Predominantly Clear Cell Carcinoma: Phase II trials have shown benefit of bevacizumab monotherapy after prior treatment with a cytokine. ${ }^{154}$ Bevacizumab is a category $2 \mathrm{~B}$ subsequent therapy option. A phase II trial suggested benefit to temsirolimus therapy after prior treatment with a cytokine. ${ }^{155} \mathrm{~A}$ phase III trial (INTORSECT) compared the efficacy of temsirolimus versus sorafenib following first-line sunitinib as RCC treatment. ${ }^{156}$ The trial enrolled 512 patients with a performance status of 0 or 1 and either clear cell or non-clear cell histology. Patients were randomized to receive sorafenib at $400 \mathrm{mg}$ twice daily or intravenous temsirolimus at $25 \mathrm{mg}$ weekly. The difference in PFS, the primary end point of the trial, was not statistically significant $(P=.1933)$ between the arms. PFS was 4.28 months with temsirolimus compared with 3.91 months with sorafenib. A statistically significant $O S$ advantage was observed for sorafenib. The median OS with temsirolimus was 12.27 months compared with 16.64 months with sorafenib $(P=.0144) .{ }^{156}$ However, the subgroup of individuals who had been treated with sunitinib for $\leq 180$ days and were then treated with sorafenib did not show a survival benefit. Based on this study, in patients with a shortened response to first-line TKI, mTOR inhibition may be considered as second-line therapy. ${ }^{157}$ The NCCN panel considers temsirolimus a category $2 \mathrm{~B}$ subsequent therapy option.

A post hoc analysis of the AXIS trial evaluated the efficacy of axitinib and sorafenib based on response to prior therapy, duration of prior therapy, and tumor burden in patients previously treated with sunitinib or cytokines. ${ }^{158}$ The analysis suggests that patients who have longer duration of response on first-line therapy have better outcomes; however, lack of response to first-line therapy does not preclude positive clinical outcomes with a second-line TKI. ${ }^{158}$

The primary objective of the phase II (RECORD-3) study was to assess noninferiority of firstline everolimus compared with first-line sunitinib with respect to PFS and to determine the role of firstline mTOR inhibitor in metastatic RCC. ${ }^{159}$ The median PFS after first-line sunitinib was 10.71 months compared with 7.85 months for everolimus. When patients progressed on first-line therapy, they were then crossed over to the alternative therapy and the combined PFS for the two sequences of treatment was also compared. The results indicated that the median PFS for patients treated with everolimus followed by sunitinib was 21.13 months compared with 25.79 months for those treated with sunitinib followed by everolimus (HR, 1.4; 95\% CI, 1.2-1.8). ${ }^{159}$ The median OS for first-line everolimus followed by sunitinib was 22.41 months compared with 32.03 months for first-line sunitinib followed by everolimus (HR, 1.2; 95\% CI, 0.9-1.6). ${ }^{159}$ These results support the currently recommended treatment of firstline sunitinib followed by everolimus at progression.

High-dose IL-2 as subsequent therapy is listed as a subsequent therapy option for selected patients with excellent performance status and normal organ function (category 2B).

\section{Systemic Therapy for Patients With Non-Clear Cell Carcinoma}

Clinical trials of targeted agents have predominantly focused on patients with clear cell histology versus non-clear cell due to the high prevalence of the clear cell RCC. The role of targeted agents in non-clear cell RCC warrants investigation. Therefore, according to the NCCN panel, enrollment in clinical trials is the preferred strategy for non-clear cell RCC. 
There are data indicating that targeted therapies approved for clear cell RCC may have benefit for non-clear cell RCC as well.

\section{Systemic Therapy for Non-Clear Cell Carcinoma}

There are now 2 randomized phase II studies showing activity of systemic therapy in patients with non-clear cell RCC. In addition, systematic reviews, meta-analysis of phase II studies, and retrospective studies with targeted agents show some activity in patients with non-clear cell RCC. Compared with responses in clear cell histologies, however, the response rates with these agents are significantly lower for non-clear cell carcinoma.

Sunitinib: Data from expanded-access trials, phase II trials, and retrospective analyses support clinical activity of sunitinib. ${ }^{160-167}$

A phase II trial of 31 patients with non-clear cell RCC treated with sunitinib reported an ORR of $36 \%$ (95\% CI, 19\%-52\%) and median PFS of 6.4 months (95\% CI, 4.2-8.6 months). ${ }^{165}$ In another study of 53 patients with non-clear cell RCC (papillary or chromophobe), the ORR to sunitinib or sorafenib was $23 \%$; median PFS was 10.6 months. ${ }^{161}$

Two other recent phase II studies compared treatment of sunitinib versus everolimus. In the ASPEN trial, 108 previously untreated patients were randomly assigned to either everolimus or sunitinib. ${ }^{168}$ Overall, median PFS, the primary end point of the trial, was longer in patients treated with sunitinib ( 8.3 vs 5.6 months). ${ }^{168}$ When the results were analyzed based on risk, median PFS was longer in patients with goodand intermediate-risk treated with sunitinib (14.0 vs 5.7 months and 6.5 vs 4.9 months, respectively), whereas patients with poor-risk features responded better to everolimus (median, 6.1 vs 4.0 months, respectively). ${ }^{168}$ In the ESPN trial, patients with metastatic non-clear cell RCC were randomized to treatment with everolimus or sunitinib. ${ }^{169}$ In an interim analysis of 68 patients, first-line therapy with sunitinib resulted in a median PFS of 6.1 months versus 4.1 months with first-line everolimus $(P=.6)$. No statistically significant difference was observed in final OS between the treatment arms (16.2 for first-line sunitinib vs 14.9 months with everolimus; $P=.18) .{ }^{169}$ In patients with tumors having no sarcomatoid features $(n=49)$, the median OS was 31.6 months with sunitinib and 10.5 months with everolimus $(P=.075)$.
Sunitinib is listed as preferred category 2A option for treatment-naïve patients with stage IV nonclear cell carcinoma.

Temsirolimus: A retrospective subset analysis of the global ARCC trial demonstrated benefit of temsirolimus not only in clear cell RCC but also in non-clear cell. ${ }^{119,170}$ In patients with non-clear cell RCC (predominantly papillary RCC), the median OS was 11.6 months with temsirolimus and 4.3 months with IFN- $\alpha$. This is the only reported phase III trial that included patients with RCC with non-clear cell histologies.

Randomized clinical trials in rarer subgroups of patients are often challenging. Consistent with the results of this phase III trial, a case report of a patient diagnosed with metastatic chromophobe RCC that was refractory to treatment with sunitinib showed a durable clinical response lasting 20 months on treatment with temsirolimus. ${ }^{171}$

Temsirolimus is a category 1 recommendation for patients with non-clear cell carcinoma with poor prognosis features (according to MSKCC risk criteria) and is a category $2 \mathrm{~A}$ recommendation for patients belonging to other prognostic non-clear cell risk groups.

Everolimus: The data on the benefit of everolimus in patients with non-clear cell RCC are limited. Data from subgroup analyses of an expanded-access trial and case reports support clinical use of everolimus in patients with non-clear cell RCC. ${ }^{172-174}$

The efficacy and safety of everolimus in patients with metastatic RCC of non-clear cell histology was evaluated in a subgroup of patients $(n=75)$ enrolled in the RAD1001 Expanded Access Clinical Trial in RCC (REACT). ${ }^{172}$ Median duration of treatment with everolimus was similar in the non-clear cell subgroup and in the overall REACT trial population (12.14 vs 14.0 weeks, respectively). The ORR (1.3\% vs $1.7 \%)$ and rate of stable disease (49.3\% vs $51.6 \%)$ were similar as well, suggesting similar efficacy in clear and non-clear cell RCC. ${ }^{172}$ The most commonly reported grade 3 and 4 adverse events, respectively, in the non-clear cell RCC subgroup included anemia (9.3\% and $8.0 \%)$, pleural effusion $(9.3 \%$ and $0 \%)$, dyspnea (8.0\% and $2.7 \%)$, fatigue $(8.0 \%$ and $0 \%)$, asthenia $(4.0 \%$ and $1.3 \%)$, stomatitis $(4.0 \%$ and $0 \%)$, and pneumonitis $(4.0 \%$ and $0 \%) .{ }^{172}$ In a phase II study, 49 patients with non-clear cell RCC 
previously treated with sunitinib or sorafenib were given everolimus, $10 \mathrm{mg} / \mathrm{d}$ orally until disease progression or unacceptable toxicity. ${ }^{174}$ The histology of the enrolled patients included papillary $(n=29)$, chromophobe $(n=8)$, collecting duct $(n=2)$, sarcomatoid $(n=4)$, and unclassified $(n=6) \cdot{ }^{174}$ The median PFS was 5.2 months, and the objective response rate was $10.2 \%$, with all of the responses being partial. A total of 25 patients (51\%) had stable disease; 16 patients $(32.7 \%)$ experienced disease progression despite everolimus. ${ }^{174}$ Adverse events reported in the trial, greater than grade 3 , included anemia $(10.2 \%)$, hyperglycemia $(8.2 \%)$, infection $(6.1 \%)$, and pneumonitis $(4.1 \%) .{ }^{174}$ Interim results from an ongoing phase II trial (RAPTOR) suggest that everolimus (10 mg once daily) provides an antitumor effect in previously untreated patients with advanced papillary RCC. The median PFS as assessed by the investigators was 7.3 months (95\% CI, 5.6-15.2). Safety and PFS of patients still on treatment as assessed by independent reviewers is ongoing. The NCCN panel has included everolimus as an option for patients with non-clear cell RCC (category 2A).

Sorafenib: Phase II trials and retrospective analyses support the clinical activity of sorafenib ${ }^{175-177}$ in patients with non-clear cell histologies. However, similar to sunitinib, the data indicate that, compared with clear cell type RCC, the clinical activity of these drugs expressed seems to be reduced in patients with non-clear cell histologies. In another study of 53 patients with non-clear cell RCC (papillary or chromophobe), ORR to sunitinib or sorafenib was $23 \%$, and the median PFS was 10.6 months. ${ }^{161}$

Sorafenib is listed as a category 2A option for treatment-naïve patients with stage IV non-clear cell carcinoma.

Pazopanib and Axitinib: The clinical benefit of pazopanib or axitinib has not yet been established in patients with non-clear cell RCC; ongoing clinical trials are evaluating the efficacy of these agents in the first-line and second-line settings (ClinicalTrials. org identifiers: NCT01767636, NCT01538238, and NCT01798446).

A retrospective analysis of an Italian multicenter cohort of patients with non-clear cell RCC found that treatment with pazopanib was effective and safe. ${ }^{178}$
Based on extrapolation, the NCCN panel has included these therapies as first-line therapy options for patients with relapsed or medically unresectable stage IV disease with non-clear cell histology (category 2A).

Erlotinib: The efficacy of erlotinib, an oral epidermal growth factor receptor (EGFR) TKI, was studied in patients with advanced papillary RCC. ${ }^{179}$ Among 52 patients who were given erlotinib orally once daily, the ORR was $11 \%$ (5 of 45 patients; $95 \%$ CI, 3\%-24\%) and the disease control rate (defined as stable disease for 6 weeks, or confirmed partial response or complete response using RECIST) was $64 \%$. The median OS was 27 months. ${ }^{179}$ This study demonstrated disease control and survival outcomes of interest with an expected toxicity profile for single-agent erlotinib.

The NCCN panel has included erlotinib as an option for first-line therapy for patients with relapsed or medically unresectable stage IV non-clear cell carcinoma (category 2A).

Other Therapies for Non-Clear Cell Carcinoma: A small phase II trial studied bevacizumab monotherapy in patients with papillary RCC. This study closed early because of very small and slow accrual of 5 patients; 3 patients had undergone a prior nephrectomy, 1 patient had resection of a liver metastasis, and 1 patient had received prior temsirolimus. The PFS reported for each of these patients was 25, 15, 11, 10, and 6 months. Main toxicities reported were grade $1 / 2$ toxicities, such as hypertension, creatinine elevations, and proteinuria. ${ }^{180}$

The NCCN Guidelines include bevacizumab and the panel recently added nivolumab, cabozantinib, and lenvatinib plus everolimus as treatment options (all category 2A) for patients with non-clear cell carcinoma.

\section{Chemotherapy for Metastatic RCC}

RCC treatment of RCC with sarcomatoid features and non-clear cell histologies remains a challenge. The sarcomatoid variant is an aggressive form of RCC that can occur in any histologic subtype ${ }^{181}$ and is associated with a poor prognosis. ${ }^{182-185}$ Chemotherapy plays a role in the management of a variety of sarcomas; therefore, its use in patients with sarcomatoid RCC has been explored. Gemcitabine in combination with doxorubicin or capecitabine has 
shown some activity in patients with non-clear cell or clear cell tumors with sarcomatoid features. ${ }^{186-191}$ The potential role of sunitinib in combination gemcitabine has been investigated in a phase II trial of RCC with sarcomatoid features. ${ }^{192}$ Results show that the combination is well tolerated and active, especially in patients with rapidly progressing disease. ${ }^{192}$ Ongoing trials are studying sunitinib in combination with gemcitabine compared with sunitinib alone in patients with sarcomatoid features (ClinicalTrials. gov identifier: NCT01164228).

Among the non-clear cell histologies, renal medullary carcinoma is extremely rare, constituting approximately $2 \%$ of all primary renal tumors in young people. ${ }^{193,194}$ Metastatic disease is seen at presentation in $95 \%$ of patients. ${ }^{193,194}$ Chemotherapy remains the focus of treatment for this subtype, although prognosis remains dismal.

Collecting duct carcinoma is also a rare type of non-clear cell RCC, often presenting at an advanced stage. Up to $40 \%$ of patients have metastatic spread at initial presentation, and most patients die within 1 to 3 years after primary diagnosis. ${ }^{195-198}$ Collecting duct carcinoma shares biologic features with urothelial carcinoma. Results from a multicenter prospective study, in which 23 patients with no prior therapy were treated with a combination of gemcitabine and either cisplatin or carboplatin, ${ }^{199}$ results showed a response rate of $26 \%$ and an OS of 10.5 months. ${ }^{199}$

The NCCN panel has noted in a footnote that chemotherapy is an option for treatment of clear cell and non-clear cell RCC with predominant sarcomatoid features. The chemotherapy regimens that have shown some benefit for patients with predominant sarcomatoid features include gemcitabine in combination with either doxorubicin or sunitinib (both category 2B). In addition, the panel has noted that partial responses to cytotoxic chemotherapy have been observed (gemcitabine in combination with carboplatin or cisplatin; or paclitaxel with carboplatin) in patients with other non-clear cell subtypes, such as collecting duct or medullary subtypes.

\section{Follow-up Recommendations for Relapsed or Stage IV Disease and Surgically Unresectable Disease}

The NCCN panel recommends an H\&P every 6 to 16 weeks for patients receiving systemic therapy, or more frequently as clinically indicated. Other laboratory evaluation may be performed according to requirements for the therapeutic agent being used.

Imaging tests such as CT or MRI should be performed before initiating systemic treatment/observation; subsequent imaging may be performed every 6 to 16 weeks as per the physician's discretion and the patient's clinical status. Imaging interval frequency should be altered according to rate of disease change and sites of active disease. The panel recommends additional imaging, such as CT or MRI of the head or spine and bone scan at baseline and then as clinically indicated.

\section{Supportive Care}

Supportive care remains a mainstay of therapy for all patients with metastatic RCC (see NCCN Guidelines for Palliative Care, available at NCCN.org). This includes surgery for patients with solitary brain metastasis whose disease is well controlled extracranially. Stereotactic RT, if available, is an alternative to surgery for limited-volume brain metastasis, and whole-brain irradiation is recommended for those patients with multiple brain metastases. ${ }^{200}$

Surgery also may be appropriate for selected patients with malignant spinal cord compression, or impending or actual fractures in weight-bearing bones, if the rest of the disease burden is limited or patients remain symptomatic. Additionally, RT along with bisphosphonates is considered for palliation, particularly for painful bone metastases. The frequency of clinic visits or radiographic and laboratory assessments depends on the individual needs of the patient.

Bone metastasis occurs in $30 \%$ to $40 \%$ of patients with advanced RCC. ${ }^{201-203}$ Bone lesions in patients with RCC are typically osteolytic and cause considerable morbidity, leading to skeletal-related events (SREs), including bone pain with need for surgery or RT, hypercalcemia, pathologic fractures, and spinal cord compression. Two studies of patients with bone metastases showed an improvement in bone pain using different RT modalities. ${ }^{204,205}$

The role of bone-modifying agents such as bisphosphonates (eg, zoledronic acid) has been well-established in this setting. ${ }^{206,207}$ The newer bone-modifying agent approved for use in patients with RCC that has metastasized to bone is the RANK-L inhibitor, 
denosumab. A phase III randomized trial directly compared the development of SREs in patients with multiple myeloma or bone metastases with a solid tumor (excluding breast or prostate cancer) while on either denosumab or zoledronic acid. The study enrolled 1,776 patients with bone metastases from a wide range of cancer types, including patients with RCC (6\%) not previously treated with a bisphosphonate. ${ }^{208} \mathrm{De}$ nosumab was reported to be noninferior to zoledronic acid in delaying time to first on-study SRE (HR, 0.84; $95 \% \mathrm{CI}, 0.71-0.98 ; P=.0007){ }^{208}$

\section{References}

1. Siegel RL, Miller KD, Jemal A. Cancer statistics, 2016. CA Cancer J Clin 2016;66:7-30.

2. Moch H, Gasser T, Amin MB, et al. Prognostic utility of the recently recommended histologic classification and revised TNM staging system of renal cell carcinoma: a Swiss experience with 588 tumors. Cancer 2000;89:604-614

3. Leibovich BC, Lohse CM, Crispen PL, et al. Histological subtype is an independent predictor of outcome for patients with renal cell carcinoma. J Urol 2010;183:1309-1315.

4. Choyke PL, Glenn GM, Walther MM, et al. Hereditary renal cancers. Radiology 2003;226:33-46.

5. DeVita VT Jr, Lawrence TS, Rosenberg SA. Cancer: Principles \& Practice of Oncology, 8th ed. Philadelphia, PA: Lippincott Williams \& Wilkins; 2008.

6. Cancer Stat Fact: Kidney and Renal Pelvis Cancer. Available at: http:// seer.cancer.gov/statfacts/html/kidrp.html.

7. Ficarra V, Schips L, Guille F, et al. Multiinstitutional European validation of the 2002 TNM staging system in conventional and papillary localized renal cell carcinoma. Cancer 2005;104:968-974.

8. Frank I, Blute ML, Leibovich BC, et al. Independent validation of the 2002 American Joint Committee on cancer primary tumor classification for renal cell carcinoma using a large, single institution cohort. J Urol 2005;173:1889-1892.

9. Zisman A, Pantuck AJ, Chao D, et al. Reevaluation of the 1997 TNM classification for renal cell carcinoma: T1 and T2 cutoff point at 4.5 rather than $7 \mathrm{~cm}$. better correlates with clinical outcome. J Urol 2001;166:54-58.

10. Klatte T, Patard JJ, Goel RH, et al. Prognostic impact of tumor size on pT2 renal cell carcinoma: an international multicenter experience. J Uro 2007;178:35-40; discussion 40.

11. Lam JS, Klatte T, Patard JJ, et al. Prognostic relevance of tumour size in T3a renal cell carcinoma: a multicentre experience. Eur Urol 2007;52:155-162.

12. Minervini A, Lilas L, Minervini R, Selli C. Prognostic value of nuclear grading in patients with intracapsular ( $\mathrm{pT} 1-\mathrm{pT} 2)$ renal cell carcinoma. Long-term analysis in 213 patients. Cancer 2002;94:2590-2595.

13. Dall'Oglio MF, Antunes AA, Sarkis AS, et al. Microvascular tumour invasion in renal cell carcinoma: the most important prognostic factor. BJU Int 2007;100:552-555.

14. Dall'Oglio MF, Ribeiro-Filho LA, Antunes AA, et al. Microvascular tumor invasion, tumor size and Fuhrman grade: a pathological triad for prognostic evaluation of renal cell carcinoma. J Urol 2007;178:425-428; discussion 428.

15. Lam JS, Shvarts O, Said JW, et al. Clinicopathologic and molecular correlations of necrosis in the primary tumor of patients with renal cell carcinoma. Cancer 2005;103:2517-2525.

16. Sengupta S, Lohse CM, Leibovich BC, et al. Histologic coagulative tumor necrosis as a prognostic indicator of renal cell carcinoma aggressiveness. Cancer 2005; 104:511-520.

17. Jayson M, Sanders H. Increased incidence of serendipitously discovered renal cell carcinoma. Urology 1998;51:203-205.

18. Luciani LG, Cestari R, Tallarigo $C$. Incidental renal cell carcinoma-age and stage characterization and clinical implications: study of 1092 patients (1982-1997). Urology 2000;56:58-62..
The NCCN panel recommends a bisphosphonate or a RANK ligand inhibitor for selected patients with bony metastases and creatinine clearance $\geq 30$ $\mathrm{mL} / \mathrm{min}$. Daily supplemental calcium and vitamin D are strongly recommended. Treatment for the palliation of symptoms, especially in patients with marginal performance status and evidence of metastatic disease, includes optimal pain management (see NCCN Guidelines for Adult Cancer Pain, available at NCCN.org).
19. Shuch B, Vourganti S, Ricketts CJ, et al. Defining early-onset kidney cancer: implications for germline and somatic mutation testing and clinical management. J Clin Oncol 2014;32:431-437.

20. Israel GM, Bosniak MA. How I do it: evaluating renal masses. Radiology 2005;236:441-450.

21. Lim DJ, Carter MF. Computerized tomography in the preoperative staging for pulmonary metastases in patients with renal cell carcinoma. J Urol 1993;150:1112-1114.

22. Miles D. Delaying skeletal-related events in a randomized phase 3 study of denosumab versus zoledronic acid in patients with advanced cancer: an analysis of data from patients with solid tumors. Cancer 2014;22:679-687.

23. Sheth S, Scatarige JC, Horton KM, et al. Current concepts in the diagnosis and management of renal cell carcinoma: role of multidetector ct and three-dimensional CT. Radiographics 2001;21(Spec No):237-254.

24. Hricak H, Demas BE, Williams RD, et al. Magnetic resonance imaging in the diagnosis and staging of renal and perirenal neoplasms. Radiology 1985;154:709-715.

25. Janus CL, Mendelson DS. Comparison of MRI and CT for study of renal and perirenal masses. Crit Rev Diagn Imaging 1991;32:69-118.

26. Seaman E, Goluboff ET, Ross S, Sawczuk IS. Association of radionuclide bone scan and serum alkaline phosphatase in patients with metastatic renal cell carcinoma. Urology 1996;48:692-695.

27. Shannon BA, Cohen RJ, de Bruto H, Davies RJ. The value of preoperative needle core biopsy for diagnosing benign lesions among small, incidentally detected renal masses. J Urol 2008;180:1257-1261; discussion 1261.

28. Park JW, Jo MK, Lee HM. Significance of 18 F-fluorodeoxyglucose positronemission tomography/computed tomography for the postoperative surveillance of advanced renal cell carcinoma. BJU Int 2009;103:615-619.

29. AJCC Cancer Staging Manual, Seventh Edition (2010), published by Springer Science+Business Media, LLC (SBM).

30. Eble JN, Sauter G, Epstein JI, et al, eds. World Health Organization Classification of Tumours: Pathology and Genetics of Tumours of the Urinary System and Male Genital Organs. Lyon, France: IARC Press; 2004.

31. Berger A, Brandina R, Atalla MA, et al. Laparoscopic radical nephrectomy for renal cell carcinoma: oncological outcomes at 10 years or more. J Urol 2009; 182:2172-2176.

32. Burgess NA, Koo BC, Calvert RC, et al. Randomized trial of laparoscopic v open nephrectomy. J Endourol 2007;21:610-613.

33. Chung SD, Huang KH, Lai MK, et al. Long-term follow-up of handassisted laparoscopic radical nephrectomy for organ-confined renal cell carcinoma. Urology 2007;69:652-655.

34. Gabr AH, Gdor Y, Strope SA, et al. Patient and pathologic correlates with perioperative and long-term outcomes of laparoscopic radical nephrectomy. Urology 2009;74:635-640.

35. Hemal AK, Kumar A. A prospective comparison of laparoscopic and robotic radical nephrectomy for T1-2N0M0 renal cell carcinoma. World J Urol 2009;27:89-94.

36. Hemal AK, Kumar A, Kumar R, et al. Laparoscopic versus open radical nephrectomy for large renal tumors: a long-term prospective comparison. J Urol 2007;177:862-866. 
37. Luo JH, Zhou FJ, Xie D, et al. Analysis of long-term survival in patients with localized renal cell carcinoma: laparoscopic versus open radical nephrectomy. World J Urol 2010;28:289-293.

38. Nambirajan T, Jeschke S, Al-Zahrani H, et al. Prospective, randomized controlled study: transperitoneal laparoscopic versus retroperitoneoscopic radical nephrectomy. Urology 2004;64:919-924.

39. Dash A, Vickers AJ, Schachter LR, et al. Comparison of outcomes in elective partial vs radical nephrectomy for clear cell renal cell carcinoma of 4-7 cm. BJU Int 2006;97:939-945.

40. Lau WK, Blute ML, Weaver AL, et al. Matched comparison of radical nephrectomy vs nephron-sparing surgery in patients with unilateral renal cell carcinoma and a normal contralateral kidney. Mayo Clin Proc 2000;75:1236-1242.

41. Lee CT, Katz J, Shi W, et al. Surgical management of renal tumors $4 \mathrm{~cm}$. or less in a contemporary cohort. J Urol 2000;163:730-736.

42. Leibovich BC, Blute ML, Cheville JC, et al. Nephron sparing surgery for appropriately selected renal cell carcinoma between 4 and $7 \mathrm{~cm}$ results in outcome similar to radical nephrectomy. J Urol 2004;171:1066-1070.

43. Zini L, Perrotte $P$, Capitanio U, et al. Radical versus partial nephrectomy: effect on overall and noncancer mortality. Cancer 2009;115:1465-1471.

44. Lee HJ, Liss MA, Derweesh IH. Outcomes of partial nephrectomy for clinical T1b and T2 renal tumors. Curr Opin Urol 2014;24:448-452.

45. Huang WC, Levey AS, Serio AM, et al. Chronic kidney disease after nephrectomy in patients with renal cortical tumours: a retrospective cohort study. Lancet Oncol 2006;7:735-740.

46. Go AS, Chertow GM, Fan D, et al. Chronic kidney disease and the risks of death, cardiovascular events, and hospitalization. N Engl J Med 2004;351:1296-1305.

47. Thompson RH, Boorjian SA, Lohse CM, et al. Radical nephrectomy for pT1a renal masses may be associated with decreased overall survival compared with partial nephrectomy. J Urol 2008;179:468-471; discussion $472-463$.

48. Weight CJ, Lieser G, Larson BT, et al. Partial nephrectomy is associated with improved overall survival compared to radical nephrectomy in patients with unanticipated benign renal tumours. Eur Urol 2010;58:293 298.

49. Weight CJ, Larson BT, Gao T, et al. Elective partial nephrectomy in patients with clinical T1b renal tumors is associated with improved overall survival. Urology 2010;76:631-637.

50. Kim SP, Thompson RH, Boorjian SA, et al. Comparative effectiveness for survival and renal function of partial and radical nephrectomy for localized renal tumors: a systematic review and meta-analysis. J Urol 2012;188:5157.

51. Thompson RH, Siddiqui S, Lohse CM, et al. Partial versus radical nephrectomy for 4 to $7 \mathrm{~cm}$ renal cortical tumors. J Urol 2009;182:26012606.

52. Hollingsworth JM, Miller DC, Dunn RL, et al. Surgical management of low-stage renal cell carcinoma: technology does not supersede biology. Urology 2006;67:1175-1180.

53. Shuch B, Lam JS, Belldegrun AS. Open partial nephrectomy for the treatment of renal cell carcinoma. Curr Urol Rep 2006;7:31-38.

54. Chen DY, Uzzo RG. Optimal management of localized renal cell carcinoma: surgery, ablation, or active surveillance. J Natl Compr Canc Netw 2009;7:635-642; quiz 643.

55. Tan HJ, Norton EC, Ye Z, et al. Long-term survival following partial vs radical nephrectomy among older patients with early-stage kidney cancer. JAMA 2012;307:1629-1635.

56. Gill IS, Kavoussi LR, Lane BR, et al. Comparison of 1,800 laparoscopic and open partial nephrectomies for single renal tumors. J Urol 2007;178:41-46.

57. Gong EM, Orvieto MA, Zorn KC, et al. Comparison of laparoscopic and open partial nephrectomy in clinical T1a renal tumors. J Endourol 2008;22:953-957.

58. Lane BR, Gill IS. 7-year oncological outcomes after laparoscopic and open partial nephrectomy. J Urol 2010;183:473-479.

59. Funahashi $Y$, Hattori R, Yamamoto $T$, et al. Ischemic renal damage after nephron-sparing surgery in patients with normal contralateral kidney. Eur Urol 2009;55:209-215

60. Blom JH, van Poppel H, Marechal JM, et al. Radical nephrectomy with and without lymph-node dissection: final results of European Organization for Research and Treatment of Cancer (EORTC) randomized phase 3 trial 30881. Eur Urol 2009;55:28-34.

61. Blute ML, Leibovich $\mathrm{BC}$, Cheville JC, et al. A protocol for performing extended lymph node dissection using primary tumor pathological features for patients treated with radical nephrectomy for clear cell renal cell carcinoma. J Urol 2004;172:465-469.

62. Capitanio U, Becker F, Blute ML, et al. Lymph node dissection in renal cell carcinoma. Eur Urol 2011;60:1212-1220.

63. Kuczyk M, Munch T, Machtens S, et al. The need for routine adrenalectomy during surgical treatment for renal cell cancer: the Hannover experience. BJU Int 2002;89:517-522.

64. Kuczyk M, Wegener G, Jonas U. The therapeutic value of adrenalectomy in case of solitary metastatic spread originating from primary renal cell cancer. Eur Urol 2005;48:252-257.

65. O'Malley RL, Godoy G, Kanofsky JA, Taneja SS. The necessity of adrenalectomy at the time of radical nephrectomy: a systematic review. J Urol 2009;181:2009-2017.

66. Lane BR, Tiong HY, Campbell SC, et al. Management of the adrenal gland during partial nephrectomy. J Urol 2009;181:2430-2436; discussion 2436-2437.

67. Rais-Bahrami S, Guzzo TJ, Jarrett TW, et al. Incidentally discovered renal masses: oncological and perioperative outcomes in patients with delayed surgical intervention. BJU Int 2009;103:1355-1358

68. Abouassaly R, Lane BR, Novick AC. Active surveillance of renal masses in elderly patients. J Urol 2008;180:505-508; discussion 508-509.

69. Lane BR, Abouassaly R, Gao T, et al. Active treatment of localized renal tumors may not impact overall survival in patients aged 75 years or older. Cancer 2010;116:3119-3126.

70. Bird VG, Carey RI, Ayyathurai R, Bird VY. Management of renal masses with laparoscopic-guided radiofrequency ablation versus laparoscopic partial nephrectomy. J Endourol 2009;23:81-88.

71. Campbell SC, Novick AC, Belldegrun A, et al. Guideline for management of the clinical T1 renal mass. J Urol 2009;182:1271-1279.

72. Kunkle DA, Uzzo RG. Cryoablation or radiofrequency ablation of the small renal mass : a meta-analysis. Cancer 2008;113:2671-2680.

73. O'Malley RL, Berger AD, Kanofsky JA, et al. A matched-cohort comparison of laparoscopic cryoablation and laparoscopic partial nephrectomy for treating renal masses. BJU Int 2007;99:395-398.

74. Simmons MN, Weight CJ, Gill IS. Laparoscopic radical versus partial nephrectomy for tumors $>4 \mathrm{~cm}$ : intermediate-term oncologic and functional outcomes. Urology 2009; 73:1077-1082.

75. Peycelon M, Hupertan V, Comperat E, et al. Long-term outcomes after nephron sparing surgery for renal cell carcinoma larger than $4 \mathrm{~cm}$. J Urol 2009;181:35-41.

76. Eggener SE, Yossepowitch O, Pettus JA, et al. Renal cell carcinoma recurrence after nephrectomy for localized disease: predicting survival from time of recurrence. J Clin Oncol 2006;24:3101-3106.

77. Stewart SB, Thompson RH, Psutka SP, et al. Evaluation of the National Comprehensive Cancer Network and American Urological Association Renal Cell Carcinoma Surveillance Guidelines. J Clin Oncol 2014.

78. Mucksavage P, Kutikov A, Magerfleisch L, et al. Comparison of radiographical imaging modalities for measuring the diameter of renal masses: is there a sizeable difference? BJU Int 2011;108:E232-236.

79. Smaldone MC, Fung C, Uzzo RG, Haas NB. Adjuvant and neoadjuvant therapies in high-risk renal cell carcinoma. Hematol Oncol Clin North Am 2011;25:765-791.

80. Haas NB, Manola J, Uzzo RG, et al. Adjuvant sunitinib or sorafenib for high-risk, non-metastatic renal-cell carcinoma (ECOG-ACRIN E2805): a double-blind, placebo-controlled, randomised, phase 3 trial. Lancet 2016;387:2008-2016

81. Gill IS, Kavoussi LR, Lane BR, et al. Comparison of 1,800 laparoscopic and open partial nephrectomies for single renal tumors. J Urol 2007;178:41-46.

82. Herr HW. Partial nephrectomy for incidental renal cell carcinoma. Br J Urol 1994;74:431-433.

83. Morgan WR, Zincke H. Progression and survival after renal-conserving surgery for renal cell carcinoma: experience in 104 patients and extended followup. J Urol 1990;144:852-857.

84. Adamy A, Chong KT, Chade D, et al. Clinical characteristics and outcomes of patients with recurrence 5 years after nephrectomy for localized renal cell carcinoma. J Urol 2011;185:433-438.

85. Lam JS, Shvarts O, Leppert JT, et al. Postoperative surveillance protocol for patients with localized and locally advanced renal cell carcinoma based on a validated prognostic nomogram and risk group stratification system. J Urol 2005;174:466-472; discussion 472; quiz 801.

86. Motzer RJ, Bacik J, Murphy BA, et al. Interferon-alfa as a comparative treatment for clinical trials of new therapies against advanced renal cell carcinoma. J Clin Oncol 2002;20:289-296. 
87. Mekhail TM, Abou-Jawde RM, Boumerhi G, et al. Validation and extension of the Memorial Sloan-Kettering prognostic factors model for survival in patients with previously untreated metastatic renal cell carcinoma. J Clin Oncol 2005;23:832-841.

88. Heng DY, Xie W, Regan MM, et al. Prognostic factors for overall survival in patients with metastatic renal cell carcinoma treated with vascular endothelial growth factor-targeted agents: results from a large, multicenter study. J Clin Oncol 2009;27:5794-5799.

89. Heng DY, Xie W, Regan MM, et al. External validation and comparison with other models of the International Metastatic Renal-Cell Carcinoma Database Consortium prognostic model: a population-based study. Lancet Oncol 2013;14:141-148.

90. Flanigan RC, Mickisch G, Sylvester R, et al. Cytoreductive nephrectomy in patients with metastatic renal cancer: a combined analysis. J Urol 2004;171:1071-1076.

91. Flanigan RC, Salmon SE, Blumenstein BA, et al. Nephrectomy followed by interferon alfa-2b compared with interferon alfa- $2 \mathrm{~b}$ alone for metastatic renal-cell cancer. N Engl J Med 2001;345:1655-1659.

92. Mickisch GH, Garin A, van Poppel H, et al. Radical nephrectomy plus interferon-alfa-based immunotherapy compared with interferon alfa alone in metastatic renal-cell carcinoma: a randomised trial. Lancet 2001;358:966-970.

93. Polcari AJ, Gorbonos A, Milner JE, Flanigan RC. The role of cytoreductive nephrectomy in the era of molecular targeted therapy. Int J Uro 2009;16:227-233.

94. Culp SH, Tannir NM, Abel EJ, et al. Can we better select patients with metastatic renal cell carcinoma for cytoreductive nephrectomy? Cancer 2010;116:3378-3388

95. Leibovich $\mathrm{BC}$, Han $\mathrm{KR}$, Bui $\mathrm{MH}$, et al. Scoring algorithm to predict survival after nephrectomy and immunotherapy in patients with metastatic renal cell carcinoma: a stratification tool for prospective clinical trials. Cancer 2003;98:2566-2575

96. Choueiri TK, Xie W, Kollmannsberger C, et al. The impact of cytoreductive nephrectomy on survival of patients with metastatic renal cell carcinoma receiving vascular endothelial growth factor targeted therapy. J Urol 2011;185:60-66.

97. Rosenberg SA, Mule JJ, Spiess PJ, et al. Regression of established pulmonary metastases and subcutaneous tumor mediated by the systemic administration of high-dose recombinant interleukin 2. J Exp Med 1985;161:1169-1188

98. Dutcher JP, Fisher RI, Weiss G, et al. Outpatient subcutaneous interleukin-2 and interferon-alpha for metastatic renal cell cancer: five-year follow-up of the Cytokine Working Group Study. Cancer J Sci Am 1997;3:157-162.

99. Negrier S, Escudier B, Lasset C, et al. Recombinant human interleukin-2, recombinant human interferon alfa-2a, or both in metastatic renalcell carcinoma. Groupe Francais d'Immunotherapie. N Engl J Med 1998;338:1272-1278

100. Fyfe G, Fisher RI, Rosenberg SA, et al. Results of treatment of 255 patients with metastatic renal cell carcinoma who received high-dose recombinant interleukin-2 therapy. J Clin Oncol 1995;13:688-696.

101. McDermott DF, Regan MM, Clark JI, et al. Randomized phase III tria of high-dose interleukin-2 versus subcutaneous interleukin-2 and interferon in patients with metastatic renal cell carcinoma. J Clin Oncol 2005;23:133-141.

102. Motzer RJ, Hutson TE, Tomczak $P$, et al. Overall survival and updated results for sunitinib compared with interferon alfa in patients with metastatic renal cell carcinoma. J Clin Oncol 2009;27:3584-3590.

103. Yang JC, Sherry RM, Steinberg SM, et al. Randomized study of high-dose and low-dose interleukin-2 in patients with metastatic renal cancer. J Clin Oncol 2003;21:3127-3132.

104. Leibovich BC, Blute ML, Cheville JC, et al. Prediction of progression after radical nephrectomy for patients with clear cell renal cell carcinoma: a stratification tool for prospective clinical trials. Cancer 2003;97:16631671.

105. Sternberg CN, Davis ID, Mardiak J, et al. Pazopanib in locally advanced or metastatic renal cell carcinoma: results of a randomized phase III trial. J Clin Oncol 2010;28:1061-1068

106. Sternberg CN, Hawkins RE, Wagstaff J, et al. A randomised, double-blind phase III study of pazopanib in patients with advanced and/or metastatic renal cell carcinoma: final overall survival results and safety update. Eur J Cancer 2013;49:1287-1296.

107. Motzer RJ, Hutson TE, Cella D, et al. Pazopanib versus sunitinib in metastatic renal-cell carcinoma. N Engl J Med 2013;369:722-731.
108. Motzer RJ, Hutson TE, McCann L, et al. Overall survival in renal-cell carcinoma with pazopanib versus sunitinib. N Engl J Med 2014;370:1769_ 1770 .

109. Escudier BJ, Porta C, Bono $P$, et al. Patient preference between pazopanib (Paz) and sunitinib (Sun): results of a randomized double-blind, placebocontrolled, cross-over study in patients with metastatic renal cell carcinoma (mRCC) -PISCES study, NCT 01064310 [abstract]. J Clin Oncol 2012;30(Suppl):Abstract CRA4502.

110. Motzer RJ, Hutson TE, Tomczak P, et al. Sunitinib versus interferon alfa in metastatic renal-cell carcinoma. N Engl J Med 2007;356:115-124.

111. Motzer RJ, Michaelson MD, Redman BG, et al. Activity of SU11248, a multitargeted inhibitor of vascular endothelial growth factor receptor and platelet-derived growth factor receptor, in patients with metastatic renal cell carcinoma. J Clin Oncol 2006;24:16-24.

112. Chow $L Q$, Eckhardt $S G$. Sunitinib: from rational design to clinical efficacy. J Clin Oncol 2007;25:884-896.

113. Faivre S, Delbaldo C, Vera K, et al. Safety, pharmacokinetic, and antitumor activity of SU11248, a novel oral multitarget tyrosine kinase inhibitor, in patients with cancer. J Clin Oncol 2006;24:25-35.

114. Gore ME, Szczylik C, Porta $C$, et al. Final results from the large sunitinib global expanded-access trial in metastatic renal cell carcinoma. $\mathrm{Br}$ J Cancer 2015;113:12-19.

115. Ruiz-Morales JM, Swierkowski M, Wells JC, et al. First-line sunitinib versus pazopanib in metastatic renal cell carcinoma: results from the International Metastatic Renal Cell Carcinoma Database Consortium. Eur J Cancer 2016;65:102-108.

116. Escudier B, Pluzanska A, Koralewski P, et al. Bevacizumab plus interferon alfa-2a for treatment of metastatic renal cell carcinoma: a randomised, double-blind phase III trial. Lancet 2007;370:2103-2111.

117. Rini BI, Choueiri TK, Elson P, et al. Sunitinib-induced macrocytosis in patients with metastatic renal cell carcinoma. Cancer 2008;113:1309_ 1314 .

118. Rini BI, Halabi S, Rosenberg JE, et al. Phase III trial of bevacizumab plus interferon alfa versus interferon alfa monotherapy in patients with metastatic renal cell carcinoma: final results of CALGB 90206. J Clin Oncol 2010;28:2137-2143

119. Hudes $G$, Carducci $M$, Tomczak $P$, et al. Temsirolimus, interferon alfa, or both for advanced renal-cell carcinoma. N Engl J Med 2007;356:22712281 .

120. Awada A, Hendlisz A, Gil T, et al. Phase I safety and pharmacokinetics of BAY 43-9006 administered for 21 days on/7 days off in patients with advanced, refractory solid tumours. Br J Cancer 2005;92:1855-1861.

121. Clark JW, Eder JP, Ryan D, et al. Safety and pharmacokinetics of the dual action Raf kinase and vascular endothelial growth factor receptor inhibitor, BAY 43-9006, in patients with advanced, refractory solid tumors. Clin Cancer Res 2005;11:5472-5480.

122. Moore M, Hirte HW, Siu L, et al. Phase I study to determine the safety and pharmacokinetics of the novel Raf kinase and VEGFR inhibitor BAY 43-9006, administered for 28 days on/7 days off in patients with advanced, refractory solid tumors. Ann Oncol 2005;16:1688-1694.

123. Strumberg D, Richly H, Hilger RA, et al. Phase I clinical and pharmacokinetic study of the novel Raf kinase and vascular endothelial growth factor receptor inhibitor BAY 43-9006 in patients with advanced refractory solid tumors. J Clin Oncol 2005;23:965-972.

124. Wilhelm SM, Carter C, Tang L, et al. BAY 43-9006 exhibits broad spectrum oral antitumor activity and targets the RAF/MEK/ERK pathway and receptor tyrosine kinases involved in tumor progression and angiogenesis. Cancer Res 2004;64:7099-7109.

125. Escudier B, Szczylik C, Hutson TE, et al. Randomized phase II trial of firstline treatment with sorafenib versus interferon alfa-2a in patients with metastatic renal cell carcinoma. J Clin Oncol 2009;27:1280-1289.

126. Hutson TE, Lesovoy V, Al-Shukri S, et al. Axitinib versus sorafenib as firstline therapy in patients with metastatic renal-cell carcinoma: a randomised open-label phase 3 trial. Lancet Oncol 2013;14:1287-1294.

127. Rini BI, Melichar B, Ueda T, et al. Axitinib with or without dose titration for first-line metastatic renal-cell carcinoma: a randomised double-blind phase 2 trial. Lancet Oncol 2013;14:1233-1242.

128. Choueiri TK, Escudier B, Powles T, et al. Cabozantinib versus everolimus in advanced renal-cell carcinoma. N Engl J Med 2015;373:1814-1823.

129. Choueiri TK, Escudier B, Powles T, et al. Cabozantinib versus everolimus in advanced renal cell carcinoma (METEOR): final results from a randomised, open-label, phase 3 trial. Lancet Oncol 2016;17:917-927.

130. Motzer RJ, Escudier B, McDermott DF, et al. Nivolumab versus everolimus in advanced renal-cell carcinoma. N Engl J Med 2015;373:1803-1813. 
131. Motzer RJ, Sharma P, McDermott DF, et al. CheckMate 025 phase III trial: outcomes by key baseline factors and prior therapy for nivolumab (NIVO) versus everolimus (EVE) in advanced renal cell carcinoma (RCC) [abstract]. J Clin Oncol 2016;34(Suppl):Abstract 498.

132. Cella D, Escudier B, Rini B, et al. Patient-reported outcomes for axitinib vs sorafenib in metastatic renal cell carcinoma: phase III (AXIS) trial. Br J Cancer 2013;108:1571-1578.

133. Escudier BJ, Motzer RJ, Sharma P, et al. Treatment beyond progression with nivolumab (nivo) in patients (pts) with advanced renal cell carcinoma (aRCC) in the phase III CheckMate 025 study [abstract]. J Clin Oncol 2016;34(Suppl):Abstract 4509.

134. Motzer RJ, Hutson TE, Glen H, et al. Lenvatinib, everolimus, and the combination in patients with metastatic renal cell carcinoma: a randomised, phase 2, open-label, multicentre trial. Lancet Oncol 2015;16:1473-1482.

135. Motzer RJ, Hutson TE, Ren M, et al. Independent assessment of lenvatinib plus everolimus in patients with metastatic renal cell carcinoma. Lancet Oncol 2016;17:e4-5.

136. Sonpavde G, Hutson TE, Rini BI. Axitinib for renal cell carcinoma. Expert Opin Investig Drugs 2008;17:741-748.

137. Rini BI, Escudier B, Tomczak P, et al. Comparative effectiveness of axitinib versus sorafenib in advanced renal cell carcinoma (AXIS): a randomised phase 3 trial. Lancet 2011;378:1931-1939.

138. Motzer RJ, Escudier B, Tomczak P, et al. Axitinib versus sorafenib as second-line treatment for advanced renal cell carcinoma: overall survival analysis and updated results from a randomised phase 3 trial. Lancet Oncol 2013;14:552-562.

139. Rini BI, de La Motte Rouge T, Harzstark AL, et al. Five-year survival in patients with cytokine-refractory metastatic renal cell carcinoma treated with axitinib. Clin Genitourin Cancer 2013;11:107-114.

140. Motzer RJ, Escudier B, Oudard S, et al. Efficacy of everolimus in advanced renal cell carcinoma: a double-blind, randomised, placebo-controlled phase III trial. Lancet 2008;372:449-456.

141. Motzer RJ, Escudier B, Oudard S, et al. Phase 3 trial of everolimus for metastatic renal cell carcinoma: final results and analysis of prognostic factors. Cancer 2010;116:4256-4265.

142. Escudier B, Eisen T, Stadler WM, et al. Sorafenib in advanced clear-cell renal-cell carcinoma. N Engl J Med 2007;356:125-134.

143. Escudier B, Eisen T, Stadler WM, et al. Sorafenib for treatment of renal cell carcinoma: final efficacy and safety results of the phase III treatment approaches in renal cancer global evaluation trial. J Clin Oncol 2009;27:3312-3318.

144. Di Lorenzo G, Carteni G, Autorino R, et al. Phase II study of sorafenib in patients with sunitinib-refractory metastatic renal cell cancer. J Clin Oncol 2009;27:4469-4474.

145. Garcia JA, Hutson TE, Elson P, et al. Sorafenib in patients with metastatic renal cell carcinoma refractory to either sunitinib or bevacizumab. Cancer 2010;116:5383-5390.

146. Motzer RJ, Rini BI, Bukowski RM, et al. Sunitinib in patients with metastatic renal cell carcinoma. JAMA 2006;295:2516-2524.

147. Dudek AZ, Zolnierek J, Dham A, et al. Sequential therapy with sorafenib and sunitinib in renal cell carcinoma. Cancer 2009;115:61-67.

148. Eichelberg C, Heuer R, Chun FK, et al. Sequential use of the tyrosine kinase inhibitors sorafenib and sunitinib in metastatic renal cell carcinoma: a retrospective outcome analysis. Eur Urol 2008;54:1373-1378.

149. Sablin MP, Negrier S, Ravaud A, et al. Sequential sorafenib and sunitinib for renal cell carcinoma. J Urol 2009;182:29-34; discussion 34.

150. Shepard DR, Rini BI, Garcia JA, et al. A multicenter prospective trial of sorafenib in patients (pts) with metastatic clear cell renal cell carcinoma (mccRCC) refractory to prior sunitinib or bevacizumab [abstract]. J Clin Oncol 2008;26(Suppl):Abstract 5123

151. Zimmermann K, Schmittel A, Steiner U, et al. Sunitinib treatment for patients with advanced clear-cell renal-cell carcinoma after progression on sorafenib. Oncology 2009;76:350-354.

152. Hainsworth JD, Rubin MS, Arrowsmith ER, et al. Pazopanib as secondline treatment after sunitinib or bevacizumab in patients with advanced renal cell carcinoma: a Sarah Cannon Oncology Research Consortium Phase II Trial. Clin Genitourin Cancer 2013;11:270-275.

153. Matrana MR, Duran C, Shetty A, et al. Outcomes of patients with metastatic clear-cell renal cell carcinoma treated with pazopanib after disease progression with other targeted therapies. Eur J Cancer 2013;49:3169-3175.

154. Yang JC, Haworth L, Sherry RM, et al. A randomized trial of bevacizumab, an anti-vascular endothelial growth factor antibody, for metastatic renal cancer. N Engl J Med 2003;349:427-434.
155. Atkins MB, Hidalgo M, Stadler WM, et al. Randomized phase II study of multiple dose levels of CCI-779, a novel mammalian target of rapamycin kinase inhibitor, in patients with advanced refractory renal cell carcinoma J Clin Oncol 2004;22:909-918.

156. Hutson TE, Escudier B, Esteban E, et al. Randomized phase III trial of temsirolimus versus sorafenib as second-line therapy after sunitinib in patients with metastatic renal cell carcinoma. J Clin Oncol 2014:32:760_ 767.

157. Hwang C, Heath EI. The Judgment of Paris: treatment dilemmas in advanced renal cell carcinoma. J Clin Oncol 2014;32:729-734.

158. Escudier B, Michaelson MD, Motzer RJ, et al. Axitinib versus sorafenib in advanced renal cell carcinoma: subanalyses by prior therapy from a randomised phase III trial. Br J Cancer 2014;110:2821-2828.

159. Motzer RJ, Barrios CH, Kim TM, et al. Phase II randomized trial comparing sequential first-line everolimus and second-line sunitinib versus first-line sunitinib and second-line everolimus in patients with metastatic renal cell carcinoma. J Clin Oncol 2014;32:2765-2772.

160. Gore ME, Szczylik C, Porta C, et al. Safety and efficacy of sunitinib for metastatic renal-cell carcinoma: an expanded-access trial. Lancet Oncol 2009;10:757-763.

161. Choueiri TK, Plantade A, Elson $P$, et al. Efficacy of sunitinib and sorafenib in metastatic papillary and chromophobe renal cell carcinoma. J Clin Oncol 2008;26:127-131.

162. Tannir NM, Plimack E, Ng C, et al. A phase 2 trial of sunitinib in patients with advanced non-clear cell renal cell carcinoma. Eur Urol 2012;62:1013-1019.

163. Plimack ER, Jonasch $\mathrm{E}$, Bekele $\mathrm{BN}$, et al. Sunitinib in papillary renal cell carcinoma (pRCC): results from a single-arm phase II study [abstract]. J Clin Oncol 2010;28(Suppl):Abstract 4604.

164. Ravaud A, Oudard S, Gravis-Mescam G, et al. First-line sunitinib in type I and II papillary renal cell carcinoma (PRCC): SUPAP, a phase II study of the French Genito-Urinary Group (GETUG) and the Group of Early Phase trials (GEP) [abstract]. J Clin Oncol 2009;27(Suppl):Abstract 5146

165. Lee JL, Ahn JH, Lim HY, et al. Multicenter phase II study of sunitinib in patients with non-clear cell renal cell carcinoma. Ann Oncol 2012;23:2108-2114.

166. Molina AM, Feldman DR, Ginsberg MS, et al. Phase II trial of sunitinib in patients with metastatic non-clear cell renal cell carcinoma. Invest New Drugs 2012;30:335-340. Available at: http://www.ncbi.nlm.nih.gov/ pubmed/20711632.

167. Shi HZ, Tian J, Li CL. Safety and efficacy of sunitinib for advanced nonclear cell renal cell carcinoma. Asia Pac J Clin Oncol 2015;11:328-333.

168. Armstrong AJ, Broderick $S$, Eisen $T$, et al. Final clinical results of a randomized phase II international trial of everolimus vs. sunitinib in patients with metastatic non-clear cell renal cell carcinoma (ASPEN) [abstract]. J Clin Oncol 2015;33(Suppl):Abstract 4507.

169. Tannir NM, Jonasch E, Albiges L, et al. Everolimus versus sunitinib prospective evaluation in metastatic non-clear cell renal cell carcinoma (ESPN): a randomized multicenter phase 2 trial. Eur Urol 2016;69:866874.

170. Dutcher JP, de Souza P, McDermott D, et al. Effect of temsirolimus versus interferon-alpha on outcome of patients with advanced renal cell carcinoma of different tumor histologies. Med Oncol 2009;26:202-209.

171. Venugopal B, Ansari J, Aitchison M, et al. Efficacy of temsirolimus in metastatic chromophobe renal cell carcinoma. BMC Urol 2013;13:26.

172. Blank CU, Bono P, Larkin JMG, et al. Safety and efficacy of everolimus in patients with non-clear cell renal cell carcinoma refractory to VEGFtargeted therapy: subgroup analysis of REACT [abstract]. J Clin Oncol 2012;30(Suppl):Abstract 402.

173. Larkin JM, Fisher RA, Pickering LM, et al. Chromophobe renal cell carcinoma with prolonged response to sequential sunitinib and everolimus. J Clin Oncol 2011;29:e241-242.

174. Koh Y, Kim JY, Lim HY, et al. Phase II trial of RAD001 in renal cell carcinoma patients with non-clear cell histology [abstract]. J Clin Oncol 2012;30(Suppl):Abstract 4544.

175. Stadler WM, Figlin RA, McDermott DF, et al. Safety and efficacy results of the advanced renal cell carcinoma sorafenib expanded access program in North America. Cancer 2010;116:1272-1280.

176. Beck J, Procopio G, Bajetta E, et al. Final results of the European Advanced Renal Cell Carcinoma Sorafenib (EU-ARCCS) expandedaccess study: a large open-label study in diverse community settings. Ann Oncol 2011;22:1812-1823.

177. Unnithan J, Vaziri S, Wood DP Jr, et al. Characterization of type II papillary renal cell carcinoma and efficacy of sorafenib [abstract]. Presented 
at the 2008 Genitourinary Cancers Symposium; February 14-16, 2008; San Francisco, California. Abstract 409.

178. Buti S, Bersanelli M, Maines F, et al. First-line pazopanib in non-clear cell renal carcinoma: the Italian retrospective multicenter PANORAMA study [abstract].J Clin Oncol 2016;34(Suppl):Abstract e16081.

179. Gordon MS, Hussey M, Nagle RB, et al. Phase II study of erlotinib in patients with locally advanced or metastatic papillary histology renal cell cancer: SWOG S0317. J Clin Oncol 2009;27:5788-5793.

180. Irshad $\mathrm{T}$, Olencki $\mathrm{T}$, Zynger $\mathrm{DL}$, et al. Bevacizumab in metastatic papillary renal cell carcinoma (PRCC) [abstract]. J Clin Oncol 2011;29(Suppl):Abstract e15158.

181. Chowdhury S, Matrana MR, Tsang C, et al. Systemic therapy for metastatic non-clear-cell renal cell carcinoma: recent progress and future directions. Hematol Oncol Clin North Am 2011;25:853-869.

182. Patard JJ, Leray E, Rioux-Leclercq N, et al. Prognostic value of histologic subtypes in renal cell carcinoma: a multicenter experience. J Clin Oncol 2005;23:2763-2771

183. Cheville JC, Lohse CM, Zincke H, et al. Comparisons of outcome and prognostic features among histologic subtypes of renal cell carcinoma. Am J Surg Pathol 2003;27:612-624.

184. Cheville JC, Lohse CM, Zincke H, et al. Sarcomatoid renal cell carcinoma: an examination of underlying histologic subtype and an analysis of associations with patient outcome. Am J Surg Pathol 2004;28:435-441.

185. Shuch B, Bratslavsky G, Linehan WM, Srinivasan R. Sarcomatoid renal cell carcinoma: a comprehensive review of the biology and current treatment strategies. Oncologist 2012;17:46-54.

186. Nanus DM, Garino A, Milowsky MI, et al. Active chemotherapy for sarcomatoid and rapidly progressing renal cell carcinoma. Cance 2004;101:1545-1551.

187. Dutcher JP, Nanus D. Long-term survival of patients with sarcomatoid renal cell cancer treated with chemotherapy. Med Oncol 2011:28:15301533.

188. Haas NB, Lin X, Manola J, et al. A phase II trial of doxorubicin and gemcitabine in renal cell carcinoma with sarcomatoid features: ECOG 8802. Med Oncol 2012;29:761-767.

189. Richey SL, Ng C, Lim ZD, et al. Durable remission of metastatic renal cell carcinoma with gemcitabine and capecitabine after failure of targeted therapy. J Clin Oncol 2011;29:e203-205.

190. Tannir NM, Thall PF, Ng CS, et al. A phase II trial of gemcitabine plus capecitabine for metastatic renal cell cancer previously treated with immunotherapy and targeted agents. J Urol 2008;180:867-872; discussion 872.

191. Stadler WM, Halabi S, Rini B, et al. A phase II study of gemcitabine and capecitabine in metastatic renal cancer: a report of Cancer and Leukemia Group B protocol 90008. Cancer 2006;107:1273-1279.

192. Michaelson MD, McKay RR, Werner L, et al. Phase 2 trial of sunitinib and gemcitabine in patients with sarcomatoid and/or poor-risk metastatic renal cell carcinoma. Cancer 2015;121:3435-3443.

193. Hakimi AA, Koi PT, Milhoua PM, et al. Renal medullary carcinoma: the Bronx experience. Urology 2007;70:878-882.
194. Watanabe IC, Billis A, Guimaraes MS, et al. Renal medullary carcinoma: report of seven cases from Brazil. Mod Pathol 2007;20:914-920.

195. Srigley JR, Delahunt B. Uncommon and recently described renal carcinomas. Mod Pathol 2009;22(Suppl 2):S2-23.

196. Tokuda N, Naito $S$, Matsuzaki $O$, et al. Collecting duct (Bellini duct) renal cell carcinoma: a nationwide survey in Japan. J Urol 2006;176:40-43; discussion 43 .

197. Karakiewicz PI, Trinh QD, Rioux-Leclercq N, et al. Collecting duct renal cell carcinoma: a matched analysis of 41 cases. Eur Urol 2007;52:11401145.

198. Gupta R, Billis A, Shah RB, et al. Carcinoma of the collecting ducts of Bellini and renal medullary carcinoma: clinicopathologic analysis of 52 cases of rare aggressive subtypes of renal cell carcinoma with a focus on their interrelationship. Am J Surg Pathol 2012;36:1265-1278.

199. Oudard S, Banu E, Vieillefond A, et al. Prospective multicenter phase II study of gemcitabine plus platinum salt for metastatic collecting duct carcinoma: results of a GETUG (Groupe d'Etudes des Tumeurs UroGenitales) study. J Urol 2007;177:1698-1702.

200. Fokas E, Henzel M, Hamm K, et al. Radiotherapy for brain metastases from renal cell cancer: should whole-brain radiotherapy be added to stereotactic radiosurgery?: analysis of 88 patients. Strahlenther Onkol 2010;186:210217.

201. Zekri J, Ahmed N, Coleman RE, Hancock BW. The skeletal metastatic complications of renal cell carcinoma. Int J Oncol 2001;19:379-382.

202. Schlesinger-Raab A, Treiber $U$, Zaak $D$, et al. Metastatic renal cell carcinoma: results of a population-based study with 25 years follow-up. Eur J Cancer 2008;44:2485-2495.

203. Roza T, Hakim L, van Poppel H, Joniau S. Bone-targeted therapies for elderly patients with renal cell carcinoma: current and future directions. Drugs Aging 2013;30:877-886.

204. Hunter GK, Balagamwala EH, Koyfman SA, et al. The efficacy of external beam radiotherapy and stereotactic body radiotherapy for painful spinal metastases from renal cell carcinoma. Pract Radiat Oncol 2012;2:e95-100.

205. Zelefsky MJ, Greco C, Motzer R, et al. Tumor control outcomes after hypofractionated and single-dose stereotactic image-guided intensitymodulated radiotherapy for extracranial metastases from renal cell carcinoma. Int J Radiat Oncol Biol Phys 2012;82:1744-1748.

206. Lipton A, Zheng M, Seaman J. Zoledronic acid delays the onset of skeletalrelated events and progression of skeletal disease in patients with advanced renal cell carcinoma. Cancer 2003;98:962-969.

207. Rosen LS, Gordon D, Tchekmedyian NS, et al. Long-term efficacy and safety of zoledronic acid in the treatment of skeletal metastases in patients with nonsmall cell lung carcinoma and other solid tumors: a randomized, phase III, double-blind, placebo-controlled trial. Cancer 2004;100:26132621.

208. Henry DH, Costa L, Goldwasser F, et al. Randomized, double-blind study of denosumab versus zoledronic acid in the treatment of bone metastases in patients with advanced cancer (excluding breast and prostate cancer) or multiple myeloma. J Clin Oncol 2011;29:1125-1132. 
Individual Disclosures for the Kidney Cancer Panel

\begin{tabular}{|c|c|c|c|c|}
\hline Panel Member & $\begin{array}{l}\text { Clinical Research Support/ } \\
\text { Data Safety Monitoring Board }\end{array}$ & $\begin{array}{l}\text { Scientific Advisory Boards, } \\
\text { Consultant, or Expert Witness }\end{array}$ & $\begin{array}{l}\text { Promotional Advisory } \\
\text { Boards, Consultant, or } \\
\text { Speakers Bureau }\end{array}$ & $\begin{array}{l}\text { Date } \\
\text { Completed }\end{array}$ \\
\hline Neeraj Agarwal, MD & None & $\begin{array}{l}\text { Argos; Clovis; Eisai Inc.; EMD Serono; } \\
\text { Exelixis Inc.; Merck \& Co., Inc.; Novartis } \\
\text { Pharmaceuticals Corporation; and Pfizer Inc. }\end{array}$ & None & $5 / 22 / 17$ \\
\hline Sam Bhayani, MD & $\begin{array}{l}\text { CONMED Corporation; and Intuitive Surgical, } \\
\text { Inc. }\end{array}$ & None & $\begin{array}{l}\text { Intuitive Surgical, Inc.; and } \\
\text { Surgiquest }\end{array}$ & $1 / 15 / 17$ \\
\hline William P. Bro, BS & None & None & None & $3 / 1 / 17$ \\
\hline Sam S. Chang, MD & None & None & None & $2 / 24 / 17$ \\
\hline Toni K. Choueiri, MD & $\begin{array}{l}\text { AstraZeneca Pharmaceuticals LP; Bristol-Myers } \\
\text { Squibb Company; Exelixis Inc.; Merck \& Co., Inc.; } \\
\text { Pfizer Inc.; and Tracon }\end{array}$ & $\begin{array}{l}\text { GlaxoSmithKline; Merck \& Co., Inc.; } \\
\text { Novartis Pharmaceuticals Corporation; } \\
\text { Peloton; Pfizer Inc.; Prometheus; and Roche } \\
\text { Laboratories, Inc. }\end{array}$ & None & $3 / 23 / 17$ \\
\hline Brian A. Costello, MD, MS & $\begin{array}{l}\text { ARGOS Therapeutics; and Novartis } \\
\text { Pharmaceuticals Corporation }\end{array}$ & None & None & $2 / 24 / 17$ \\
\hline Ithaar H. Derweesh, MD & Pfizer Inc. & None & None & $5 / 22 / 17$ \\
\hline Mayer Fishman, MD, PhD & $\begin{array}{l}\text { Abbott Laboratories; Acceleron; ALTOR; } \\
\text { Argos; AstraZeneca Pharmaceuticals LP; Bayer } \\
\text { HealthCare; Bristol-Myers Squibb Company; } \\
\text { Eisai Inc.; Exelixis Inc.; Genentech, Inc.; Immatics } \\
\text { Biotechnologies GmbH; Medivation; Merck \& } \\
\text { Co., Inc.; Novartis Pharmaceuticals Corporation; } \\
\text { Pfizer Inc.; Prometheus; and Takeda } \\
\text { Pharmaceuticals North America, Inc. }\end{array}$ & Alkermes; and Nektar & Exelixis Inc.; and Pfizer Inc. & $7 / 6 / 16$ \\
\hline Thomas H. Gallagher, MD & None & None & None & $8 / 26 / 16$ \\
\hline John L. Gore, MD, MS & GenomeDX Biosciences & None & None & $3 / 1 / 17$ \\
\hline Steven L. Hancock, MD & Elekta Ltd.; and Phillips Health Care & Scripps Proton Advisory Committee & None & $1 / 19 / 17$ \\
\hline Michael R. Harrison, MD & $\begin{array}{l}\text { Argos; Bristol-Myers Squibb Company; Exelixis } \\
\text { Inc.; Genentech, Inc.; and Pfizer Inc. }\end{array}$ & $\begin{array}{l}\text { Argos; AstraZeneca Pharmaceuticals LP; } \\
\text { Exelixis Inc.; and Genentech, Inc. }\end{array}$ & $\begin{array}{l}\text { Exelixis Inc.; and Genentech, } \\
\text { Inc. }\end{array}$ & $2 / 14 / 17$ \\
\hline Eric Jonasch, MD & $\begin{array}{l}\text { Exelixis Inc.; Novartis Pharmaceuticals } \\
\text { Corporation; and Pfizer Inc. }\end{array}$ & $\begin{array}{l}\text { Bristol-Myers Squibb Company; Exelixis Inc.; } \\
\text { GlaxoSmithKline; Novartis Pharmaceuticals } \\
\text { Corporation; and Pfizer Inc. }\end{array}$ & None & $4 / 6 / 17$ \\
\hline Won Kim, MD & None & Genentech, Inc.; and Pfizer Inc. & None & $2 / 25 / 17$ \\
\hline Christos Kyriakopoulos, MD & None & Exelixis Inc. & None & $2 / 24 / 17$ \\
\hline Chad LaGrange, MD & None & None & None & $1 / 9 / 17$ \\
\hline Elaine T. Lam, MD & $\begin{array}{l}\text { Argos Therapeutics, Inc.; Bristol-Myers Squibb } \\
\text { Company; Calithera Biosciences; Exelixis Inc.; } \\
\text { Genentech, Inc.; Merck \& Co., Inc.; Peloton; } \\
\text { Pfizer Inc.; and Roche Laboratories, Inc. }\end{array}$ & Bristol-Myers Squibb Company & None & $1 / 1 / 17$ \\
\hline Clayton Lau, MD & None & None & None & $5 / 15 / 15$ \\
\hline M. Dror Michaelson, MD, $\mathrm{PhD}^{\mathrm{a}}$ & $\begin{array}{l}\text { Argos; Eisai Inc.; Exelixis Inc.; Merck \& Co., Inc.; } \\
\text { Pfizer Inc.; and Tracon }\end{array}$ & $\begin{array}{l}\text { Astellas; Eisai Inc.; Exelixis Inc.; Novartis } \\
\text { Pharmaceuticals Corporation; and Pfizer Inc. }\end{array}$ & None & $4 / 24 / 17$ \\
\hline Robert J. Motzer, MD & $\begin{array}{l}\text { Bristol-Myers Squibb Company; Exelixis Inc.; } \\
\text { Genentech, Inc.; Novartis Pharmaceuticals } \\
\text { Corporation; and Roche Laboratories, Inc. }\end{array}$ & $\begin{array}{l}\text { Merck \& Co., Inc.; Novartis Pharmaceuticals } \\
\text { Corporation; and Pfizer Inc. }\end{array}$ & None & $4 / 17 / 17$ \\
\hline Thomas Olencki, DO & $\begin{array}{l}\text { Bristol-Myers Squibb Company; Genentech, Inc.; } \\
\text { Pfizer Inc.; and Tracon }\end{array}$ & Genentech, Inc. & None & $1 / 25 / 17$ \\
\hline Phillip M. Pierorazio, MD & None & None & None & $5 / 9 / 17$ \\
\hline Elizabeth R. Plimack, MD, MS & $\begin{array}{l}\text { Acceleron; AstraZeneca Pharmaceuticals LP; } \\
\text { Bristol-Myers Squibb Company; Eli Lilly and } \\
\text { Company; Merck \& Co., Inc.; Peloton; and Pfizer } \\
\text { Inc. }\end{array}$ & $\begin{array}{l}\text { AstraZeneca Pharmaceuticals LP; Bristol- } \\
\text { Myers Squibb Company; Exelixis Inc.; } \\
\text { Genentech, Inc.; and Roche Laboratories, } \\
\text { Inc. }\end{array}$ & None & $1 / 7 / 17$ \\
\hline Bruce G. Redman, DO & None & None & None & $3 / 23 / 17$ \\
\hline Brian Shuch, MD & None & None & None & $4 / 22 / 17$ \\
\hline Brad Somer, MD & None & None & None & $2 / 9 / 17$ \\
\hline Guru Sonpavde, MD & $\begin{array}{l}\text { Bayer HealthCare; Boehringer Ingelheim GmbH; } \\
\text { Celgene Corporation; Merck \& Co., Inc.; and } \\
\text { Onyx Pharmaceuticals, Inc. }\end{array}$ & None & $\begin{array}{l}\text { Agensys; Argos Therapeutics; } \\
\text { AstraZeneca Pharmaceuticals } \\
\text { LP; Bayer HealthCare; Clinical } \\
\text { Care Options/NCCN; Eisai } \\
\text { Inc.; Genentech, Inc.; Janssen } \\
\text { Pharmaceutica Products, } \\
\text { LP; Merck \& Co., Inc.; } \\
\text { Novartis Pharmaceuticals } \\
\text { Corporation; Pfizer Inc.; } \\
\text { sanofi-aventis U.S.; and } \\
\text { Uptodate }\end{array}$ & $2 / 1 / 17$ \\
\hline Jeffrey Sosman, MD & None & $\begin{array}{l}\text { Array Pharma; Genentech, Inc.; Merck \& } \\
\text { Co., Inc.; and Novartis Pharmaceuticals } \\
\text { Corporation }\end{array}$ & None & $2 / 24 / 17$ \\
\hline
\end{tabular}

The NCCN Guidelines Staff have no conflicts to disclose.

aThe following individuals have disclosed that they have a spouse/domestic partner/dependent potential conflict:

M. Dror Michaelson, MD, PhD: Jounce 